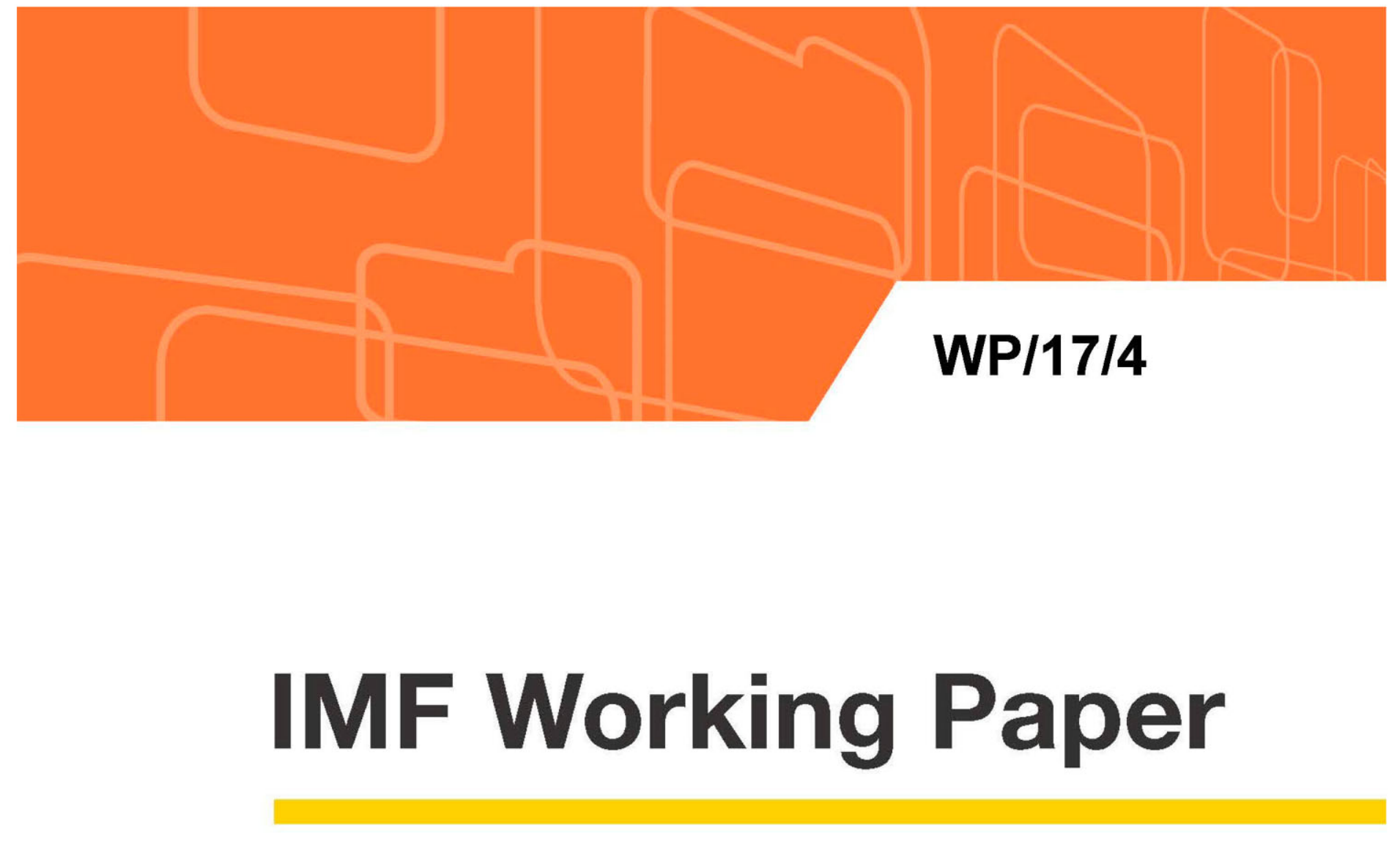

\title{
How Buoyant is the Tax System? New Evidence from a Large Heterogeneous Panel
}

by Paolo Dudine and Joao Tovar Jalles

IMF Working Papers describe research in progress by the author(s) and are published to elicit comments and to encourage debate. The views expressed in IMF Working Papers are those of the author(s) and do not necessarily represent the views of the IMF, its Executive Board, or IMF management.

$$
\text { I N T E R N A T I O N A L M O N E T A R Y F U N D }
$$




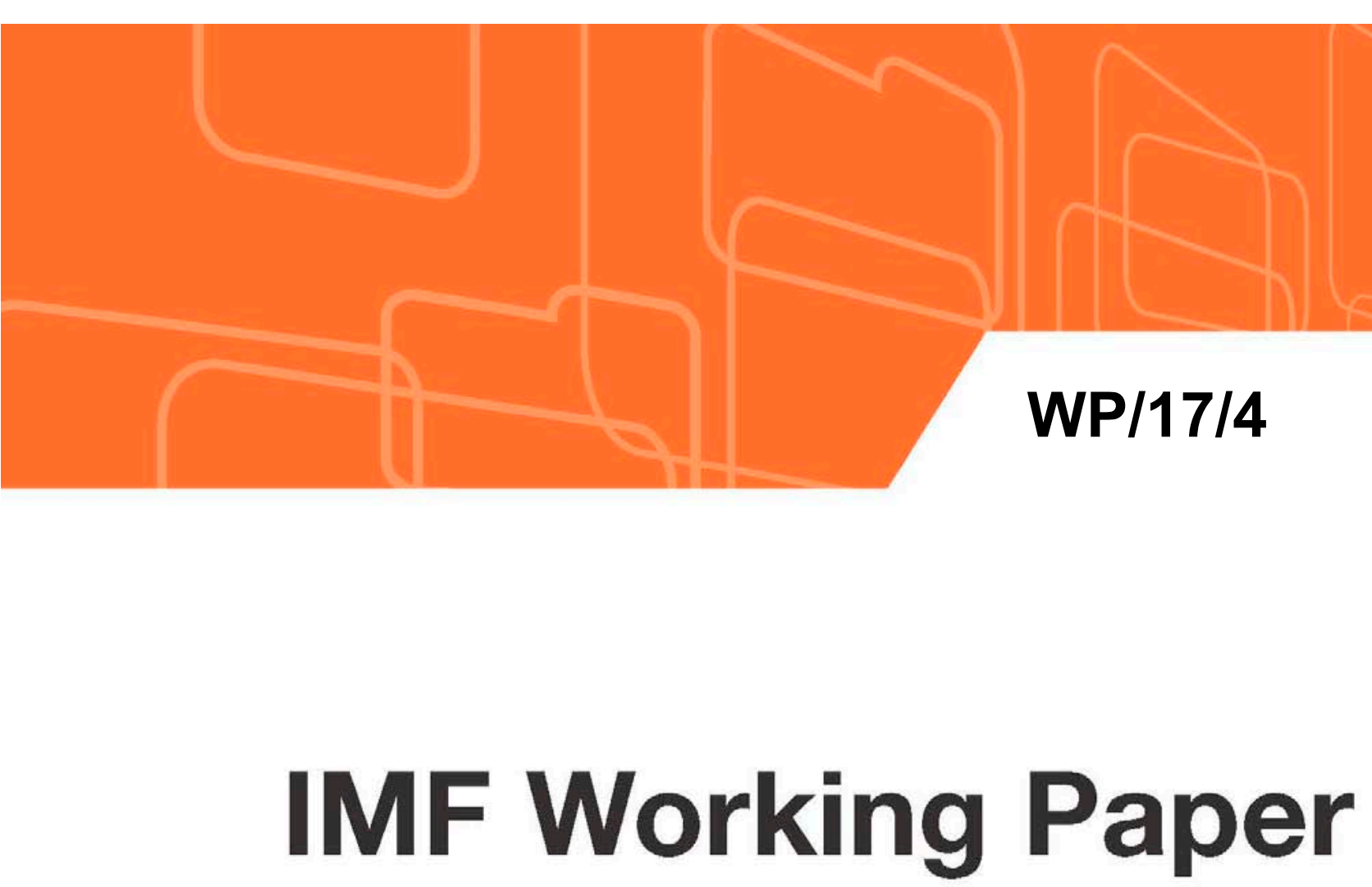

\section{How Buoyant is the Tax System? New Evidence from a Large Heterogeneous Panel}

by Paolo Dudine and Joao Tovar Jalles

IMF Working Papers describe research in progress by the author(s) and are published to elicit comments and to encourage debate. The views expressed in IMF Working Papers are those of the author(s) and do not necessarily represent the views of the IMF, its Executive Board, or IMF management.

I N T E R N A T I O N A L M O N E T A R Y F U N D 


\title{
IMF Working Paper
}

Fiscal Affairs Department

\section{How Buoyant is the Tax System? New Evidence from a Large Heterogeneous Panel Prepared by Paolo Dudine and Joao Tovar Jalles*}

Authorized for distribution by Catherine Pattillo

January 2017

IMF Working Papers describe research in progress by the author(s) and are published to elicit comments and to encourage debate. The views expressed in IMF Working Papers are those of the author(s) and do not necessarily represent the views of the IMF, its Executive Board, or IMF management.

\begin{abstract}
In this paper we provide short- and long-run tax buoyancy estimates for 107 countries (distributed between advanced, emerging and low-income) for the period 1980-2014. By means of Fully-Modified OLS and (Pooled) Mean Group estimators, we find that: i) for advanced economies both long-run and short-run buoyancies are not different from one; ii) long run tax buoyancy exceeds one in the case of CIT for advanced economies, PIT and SSC in emerging markets, and TGS for low income countries, iii) in advanced countries (emerging market economies) CIT (CIT and TGS) buoyancy is larger during contractions than during times of economic expansions; iv) both trade openness and human capital increase buoyancy while inflation and output volatility decrease it.
\end{abstract}

JEL Classification Numbers: E62, H21, H29, H68

Keywords: tax elasticity, recession, error correction model, pooled mean group, short vs long run, fiscal sustainability

Author’s E-Mail Address: pdudine@,imf.org; jjalles@,imf.org

\footnotetext{
* The authors are grateful to Vitor Gaspar, Sanjeev Gupta, Ben Clements and Era Dabla-Norris for useful suggestions. Authors also acknowledge general comments made by participants of a FAD internal seminar as well as from colleagues from the Research, European and Legal Departments. Thanks also go to Younghun Kim for excellent research assistance. The opinions expressed herein are those of the authors and do not necessarily reflect those of the IMF, its member countries or its policy. The usual disclaimer applies.
} 
Contents

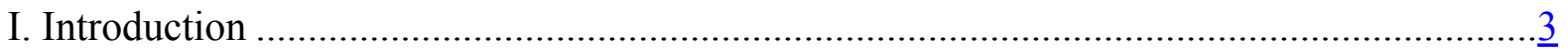

II. Estimates of Buoyancy And Elasticity...................................................................... $\frac{5}{5}$

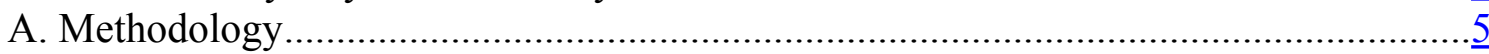

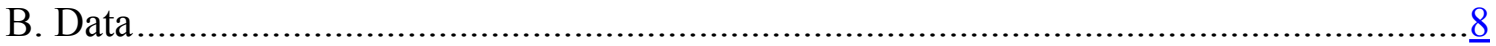

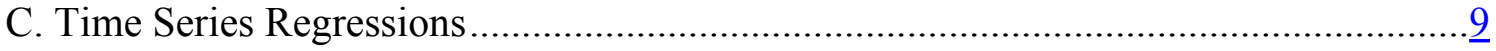

D. Panel Regression ............................................................................................ $\frac{13}{14}$

E. Robustness Checks and Estimates of Elasticity .................................................14

III. Tax Buoyancy Around Business Cycle Turning Points .............................................16

IV. Exploring Which Characteristics Matter For Tax Buoyancy …..................................19

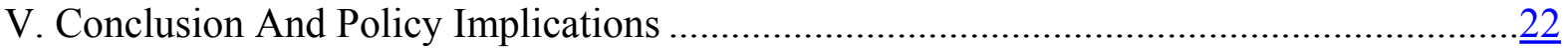

Figures

1. Inter-Quartile Range of Tax Revenues Over Time.......................................................

2. Kernel Density of FMOLS Estimates of Long-Run Buoyancies....................................11

3. Kernel Density of FMOLS Estimates of Short-Run Buoyancies .....................................12

4. Tax Revenue and Categories (Percent of GDP) Around Recession Episodes....................17

Tables

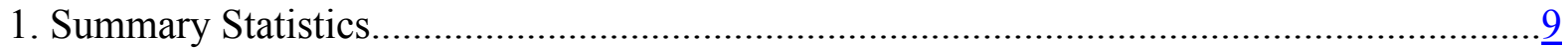

2. Summary Statistics of FMOLS Estimates of Long-Run Buoyancies ..............................11

3. Summary Statistics of FMOLS Estimates of Short-Run Buoyancies..............................12

4. Overall Tax Buoyancy by Country Group, Alternative Estimators.................................13

5. Buoyancy of Tax Revenue Components................................................................ $\frac{14}{14}$

6. Buoyancy of PIT, CIT and TGS with and without Controlling for Tax Rates ...................15

7. Overall Tax Buoyancy with and without Controlling for Inflation .............................. 16

8. Asymmetric Short-term Buoyancy over the Business Cycle......................................... $\frac{19}{21}$

9. Determinants of Tax Buoyancy: Total Taxes ............................................................. $\frac{21}{22}$

10. Determinants of Tax Buoyancy: Alternative Tax Categories ........................................

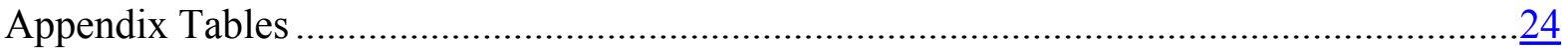




\section{INTRODUCTION}

Most countries, through time, have attempted to lift growth by increasing public expenditure, counting that the ensuing income would raise enough revenues to keep the fiscal balance from deteriorating over the long run. However, several economies have not been able to mobilize revenues through taxation to the same extent as spending went up and, therefore, resorted to internal and external borrowing to finance (growing) deficits, putting fiscal sustainability at risk. The answer to whether greater growth will raise revenue and allow keeping the fiscal balances in check depends on an important ingredient of a tax system, the so-called tax buoyancy: the measure of how tax revenues vary with changes in output. ${ }^{1}$

In this paper we ask three questions. How large are tax buoyancies, for different groups of countries, and for different types of revenues, both over the long run and in the short run? Do tax buoyancies remain the same during the different phases of the business cycle? What structural characteristics of an economy determine tax buoyancy?

An examination of tax buoyancy is crucial for tax policy formulation and design for three reasons. First, tax buoyancy illustrates the role that revenue policy plays in ensuring fiscal sustainability in the long run, and in stabilizing the economy over the business cycle in the short-run. Revenues which move in tandem with output in the long-run help support the sustainability of fiscal policy; revenues that are very responsive to changes in output in the short-run ensure that the tax system functions as a good output stabilizer. ${ }^{2}$ In this perspective, understanding how and why revenues react to changes in income during the business cycle is also important from the point of view of the government's intertemporal budget constraint and tax smoothing objectives. Second, assessing country-specific tax buoyancy allows to ascertain if the government is keeping tax mobilization in line with economic activity, and estimating individual tax buoyancies helps identify the weak and strong spots of the revenue system. Both analyses allow the fiscal authorities (i) to ascertain if more effort should be put into mobilizing revenues, and (ii) to better direct this effort at increasing the share of those taxes that better respond to a sustained increase in income. Finally, knowing which structural factors likely affect buoyancy helps anticipating how all the considerations above would change as the economy develops.

\footnotetext{
${ }^{1}$ A buoyancy of one would imply that an extra one percent of GDP would increase tax revenue also by one percent, thus leaving the tax-to-GDP ratio unchanged. When tax buoyancy exceeds one, however, tax revenue increases more than GDP, which could and potentially lead to reductions in the deficit ratio. A buoyancy greater than unity over the long run is a desirable feature of a tax system if there is increasing demand for public services and if a country would like to pursue relative financial stability. If buoyancy is low, discretionary changes may make up for it, but these can be lagged and disproportionally high (Blanchard, Dell'Aricia and Mauro, 2010).

${ }^{2}$ In principle, the buoyancy of revenue reflects both the effect of automatic stabilizers and of discretionary policy changes. To the extent that the latter are systematically driven by a reaction function, short-run buoyancy estimates may be biased and hence may not necessarily be interpreted as reflecting only the effect of automatic stabilizers. For a recent study on the stabilizing function of fiscal policy in a panel of heterogeneous countries between 1980 and 2013, see April 2015 Fiscal Monitor.
} 
Estimates of revenue buoyancies and elasticities abound in the literature, both for individual and groups of countries (mostly OECD), both for national and subnational levels. For example, Giorno and others (1995), Girouard and Andre (2005), and Belinga and others (2014) estimate revenue elasticities for OECD countries, while Bouthevillan and others (2001) inspect euro area countries. They generally find that corporate income taxes are more buoyant than personal income taxes. Their results show that, if one were to account for individual shares in total revenue, the buoyancy of total tax revenue would be slightly above one. Choudhry (1979) estimates the elasticity of tax revenue of the US, UK, Malaysia and Kenya. At the sub-national level, Bruce, Fox and Tuttle (2006) provide estimates for the States of the US. Turning to developing countries, Osoro $(1993,1995)$ provides tax elasticities estimates in Tanzania; Ariyo (1997) evaluates the productivity of the Nigerian tax system; Chipeta (1998) studies the effects of tax reforms on tax yields in Malawi; Kusi (1998) studies Ghana's tax reform and revenue productivity; Bilquees (2004) studies the elasticity and buoyancy of the tax system in Pakistan; Upender (2008) focuses on India; and Cotton (2012) looks at Trinidad and Tobago.

In this paper, we exploit a new and more comprehensive tax revenue dataset that allows us to estimate tax buoyancies for 107 countries, split between advanced, emerging and low income economies, using data spanning, depending on the country group, as early as 1980 and as recent as 2014. More specifically, we contribute to the most recent literature by:

- $\quad$ estimating both short and long-run tax buoyancies (and formally testing equality to one) for each country and country-group using both time series (Fully Modified OLS) and panel data techniques (Mean Group estimators) for four categories of tax revenues, namely personal income tax (PIT), corporate income tax (CIT), taxes on goods and services (TGS), and social security contributions (SSC);

- $\quad$ analyzing the influence of business cycle's turning points on tax buoyancy, with a particular focus on the Global Financial Crisis (GFC);

- $\quad$ assessing which macro and structural characteristics matter more to explain crosscountry differences in tax buoyancy estimates.

Our results suggest that:

- $\quad$ Long-run revenue buoyancy is not different from one. This implies that revenues ensure long-run sustainability only if permanent increases in spending deliver at least the same increase in long-run GDP. Short-run revenue buoyancy is not different from one in advanced economies, but it tends to exceed one in emerging markets and low income countries. Revenues tend to function more as an output stabilizer in the latter than in the former group of countries.

- When it comes to individual taxes, long-run tax buoyancy exceeds one in the case of CIT for advanced economies, PIT and SSC in emerging markets, and TGS for low income countries. Over the short-run, the CIT is buoyant (with a value exceeding 
one) in all country groups, consistently with the findings in the literature on OECD countries.

- $\quad$ Over the phase of the cycle, in advanced countries only CIT buoyancy is larger during contractions than during times of economic expansions, suggesting that this tax category better stabilizes output during bad times. In emerging market economies, this effect is attributed to the TGS.

- $\quad$ Finally, both trade openness and human capital increase tax buoyancies, while inflation and output volatility decrease them.

The remainder of the paper is organized as follows. Section 2 discusses our estimates of buoyancies. It describes the methodology and data that we use, and our results. Section 3 discusses buoyancy around business cycle turning points. Section 5 explores which country characteristics matter for tax buoyancy. The last section concludes and outlines some policy implications.

\section{ESTIMATES OF BUOYANCY AND ELASTICITY}

In this section we provide estimates of long- and short-run tax buoyancies. For completeness and robustness, we use both time series and panel data techniques. We show that, for a representative country within a country group (advanced economies, emerging markets, or low-income developing countries), results are similar irrespective of the estimation technique that is used. This suggests that, lacking enough data on at a country level, panel estimates are very good approximations. We also argue and show that, generally speaking, estimates of tax buoyancy and elasticity do not differ from one another.

\section{A. Methodology}

The buoyancy of a tax system measures the total response of tax revenue both to changes in national income and to discretionary changes in tax policies over time, and it is traditionally interpreted as the percentage change in revenue associated to a one percent change in income. Though closely related to buoyancy, the elasticity of the tax system measures instead the responsiveness of tax revenue to changes in national income keeping all other parameters (including tax legislation) constant (Skeete, Coppin and Boamah, 2003). When the elasticity of major revenue sources is low (for example, owing to the rigidity of the tax base or the presence of tax evasion and/or avoidance), governments raise additional resources through discretionary measures. In this case, the growth of tax revenue comes through high buoyancy rather than high elasticity. ${ }^{3}$

\footnotetext{
${ }^{3}$ In some sense, elasticity is more appropriately used to estimate the impact on revenues from, say, an unexpected decline in the tax base (owing, for example, to a natural disaster), or the increase in, say, personal income tax revenues over time if other provisions (income brackets, deductions, and allowances) remain the same. Buoyancy on the other hand, more appropriately measures past revenue developments or the combined effects of a package of reforms.
} 
Revenue buoyancy and elasticity are traditionally estimated by means of a regression of the natural logarithm of tax revenue (or a subcomponent) on the natural logarithm of GDP, additionally controlling for tax rates and other parameters of the system in the case of elasticity estimates. This is the approach that we follow in this paper. ${ }^{4}$

Two issues emerge when estimating tax buoyancy and elasticity. The first relates to the time span over which the response of revenues to GDP is considered. Over the long-run it is generally expected that buoyancy is equal to one. If not, at least on theoretical grounds, there would come a point when revenues exceed 100 percent of their respective bases. However, over the short-run, buoyancies can be different from one and they can be different across revenue items. For example, in the short-run the PIT may increase more than proportionally to an increase in income if the revenue brackets or other deductions are not adjusted for inflation. Similarly, owing to provisions such as loss-carry forward, CIT collection might increase less than VAT collection during the economic rebound that follows a recession.

A second issue relates to the time series properties of revenue and income, specifically the amount of inertia that each has and whether or not there exists a stable long-run relationship between them. In general, both the natural logarithm of tax revenue (or a component) and the natural logarithm of GDP are integrated and it is reasonable to expect that they are cointegrated. If data supports this prior, cointegration techniques must be used.

With these considerations in mind, we base our analysis on the unrestricted error correction $\operatorname{ARDL}(p, q)$ representation:

$\Delta \ln y_{i t}=\varphi_{i} y_{i t-1}+\beta_{i}^{\prime} x_{i t-1}+\sum_{j=1}^{p-1} \lambda_{i j} \Delta \ln y_{i t-j}+\sum_{q=1}^{q-1} \gamma_{i j}^{\prime} \Delta \ln x_{i t-j}+\mu_{i}+\xi_{i t}, i=1,2, \ldots, N ; t=1,2, \ldots, T$

where $y_{i t}$ is the natural logarithm of a scalar dependent tax revenue variable, $x_{i t}$ is the $k \times 1$ vector of regressors for group $I$ (which includes the natural logarithm of GDP but also other potential controls), $\mu_{i}$ represents the fixed effects, $\phi_{i}$ is a scalar coefficient on the lagged dependent variable. $\beta^{\prime}{ }_{i}$ 's is the $k \times 1$ vector of coefficients on explanatory variables, $\lambda_{i j}$ 's are scalar coefficients on lagged first-differences of dependent variables, and $\gamma_{i j}$ 's are $k \times 1$

\footnotetext{
${ }^{4}$ Tax buoyancy and elasticity can be calculated using several alternative methods: i) the traditional model used to estimate tax buoyancy requires GDP or a proxy tax base (in which case the elasticity of the tax base to GDP also has to be estimated, as in Girouard and Andre, 2005) to be a determinant of tax revenue; ii) the proportional adjustment method involves isolating the data on discretionary revenue changes based on data provided by government; iii) the dummy variable method introduces a dummy variable for each year in which there was an exogenous tax policy change; iv) the constant rate structure involves collecting statistics on actual tax receipts and data on monetary value of the legal tax bases and corresponding revenues; the tax bracket of the base year is then multiplied by the corresponding base values and the products summed up; v) the divisia index introduces a proxy for discretionary tax measures.
} 
coefficient vectors on first-differences of explanatory variables and their lagged values. We assume that the disturbances $\xi_{i t}$ in the ARDL model are independently distributed across $i$ and $t$, with zero means and constant variances. Equation (1) means that developments in tax revenues can be explained by a distributed lag of order $p$ of the dependent variable, and a distributed lag of order $q$ of GDP.

Assuming that $\phi_{i}<0$ for all $i$, there exists a long-run relationship between $y_{i t}$ and $x_{i t}$ :

$$
\ln y_{i t}=\theta_{i}^{\prime} \ln x_{i t}+\eta_{i t}, i=1,2, \ldots, N ; t=1,2, \ldots, T
$$

where $\theta_{i}^{\prime}=-\beta_{i}^{\prime} / \phi_{i}$ is the $k \times 1$ vector of the long-run coefficients, and $\eta_{i t}$ 's are stationary with possible non-zero means (including fixed effects). Equation (1) can then be rewritten as:

$\Delta \ln y_{i t}=\varphi_{i} \eta_{i t-1}+\sum_{j=1}^{p-1} \lambda_{i j} \Delta \ln y_{i t-j}+\sum_{q=1}^{q-1} \gamma_{i j}^{\prime} \Delta \ln x_{i t-j}+\mu_{i}+\xi_{i t}, i=1,2, \ldots, N ; t=1,2, \ldots, T$

where $\eta_{i t-1}$ is the error correction term (that is, the deviation of variables at a certain point in time from their long run equilibrium), and $\phi_{i}$ is measures the speed of adjustment towards the long-run equilibrium.

This specification allows capturing the idea that an equilibrium relationship links revenue and GDP in the long-run, but that the dependent variable may deviate from its equilibrium path in the short-run (due, e.g., to shocks that may be persistent). We estimate equation (3) for both aggregate tax revenue and revenue categories: the PIT, the CIT, TGS, and SSC.

Equation (3) can be estimated either country by country, or on the entire panel of countries. Exploiting the panel dimension has three main advantages: first, it enables bypassing lack of degree-of-freedom related to (potentially) short spanned time series at the cross-section level; second, hypothesis testing is more powerful and inference stronger than when using time series techniques on only one country; third, cross-sectional information reduces the probability of a spurious regression (Barnerjee, 1999)..$^{5}$ In addition, information on discretionary tax measures is generally not available for a large number of countries (in particular emerging and low income countries), which complicates estimating tax elasticities. In the context of a large panel of countries such as ours, the effects of discretionary tax measures would either be captured by time effects or they would cancel each other out over time and over the cross-sectional dimension. Hence, estimates of buoyancy can also be seen as a good approximate estimate of tax elasticities. However, panel techniques, in particular the Pooled Mean Group (see below), risk imposing an unwarranted amount of homogeneity on the data, which could severely bias the estimates especially of long-run buoyancy.

\footnotetext{
${ }^{5}$ Recall that $\mathrm{t}$-ratios are invalid for the estimations if error terms are nonstationary.
} 
To check the extent to which homogeneity could be a problem, we first estimate the parameters in equation (3) with Fully Modified Ordinary Least Squares (FMOLS) on a country by country basis, and we study summary statistics of these estimates, arranged by country group and type of tax revenue. FMOLS (Phillips and Hansen, 1990) employs a semiparametric correction to eliminate the problems caused by the long-run correlation between (a) the deviations from long-run equilibrium and (b) the innovations in the stochastic process that each regressor follows.

We then estimate the parameters in equation (3) using panel data methods. Here, we consider the Mean Group (MG) estimator (Pesaran and Smith, 1995) and the Pooled Mean Group (PMG) estimator, which involves both pooling and averaging (Pesaran and others, 1999). The MG approach consists of estimating equation (3) separately for each country and computing averages of the country-specific coefficients (Evans, 1997; Lee and others, 1997). This allows for heterogeneity of all the estimated parameters. The PMG estimator allows the intercepts, short-run coefficients and error variances to differ freely across groups, but it constrains the long-run coefficients to be the same across countries. ${ }^{6}$ The group-specific short-run coefficients and the common long-run coefficients are computed by maximum likelihood estimation. Both the MG and PMG are appropriate for the analysis of dynamic panels with both large time and cross-section dimensions, and they have the advantage of accommodating both the long-run equilibrium and the possibly heterogeneous dynamic adjustment process. In particular, these estimators allow correcting for the potential bias that could result from estimating tax buoyancy coefficients using standard fixed-effects models in the presence of nonstationary error terms, which imposing parameter homogeneity would introduce into the estimating equation.

\section{B. Data}

We use an unbalanced panel of annual tax revenue data covering 31 Advanced Economies (AE), 38 Emerging Market Economies (EME) and 38 Low Income Countries (LIC) between 1980 and 2014. The span of available data varies within each country group and across tax revenue components, in particular the data coverage from 1980 to 1995 is relatively sparse. Apart from aggregate tax revenue data, we focus on four tax categories, namely, Personal Income Tax (PIT), Corporate Income Tax (CIT), Taxes on Goods and Services (TGS) and Social Security Contributions (SSC). The source of data is the OECD when available, and the IMF World Economic Outlook (WEO) database otherwise. PIT, CIT and Value Added Tax (VAT) rates come from the IMF's Tax Policy Division database, specifically: the highest marginal rate for the PIT, the base rate for the CIT and the base rate for the VAT/TGS. Note that the country and time coverage of tax rates is smaller than that of general tax revenue data, so when used in regression analysis, this reduces the total number of observations.

\footnotetext{
${ }^{6}$ There are often good reasons to expect the long-run equilibrium relationships between variables to be similar across groups of countries, due to e.g. budget constraints, fiscal rules or even common (unobserved) factors influencing them in a similar way.
} 
Finally, GDP, output gap, and inflation data are taken from the IMF's International Financial Statistics.

A preliminary look at the overall tax revenue data for each country group between 1980-2014 is displayed in Figure 1 and summarized in Table 1. ${ }^{7}$ We observe that the share of tax revenues in GDP in advanced economies has remained relatively constant during this period with an average increase of only 2.6 percent of GDP. On the contrary, in emerging market economies, tax revenue has been increasing in relation to GDP only since 2005, while it has been steadily increasing in low-income countries since 1995, confirming the latter's group recent efforts at improving revenue mobilization. Moreover, it is visible in all three panels of Figure 1 the negative impact of the GFC on tax revenues, and while advanced economies haven't recovered yet to pre-crisis levels, both emerging and low-income countries did.

Figure 1. Inter-Quartile Range of Tax Revenues Over Time (Percent of GDP)
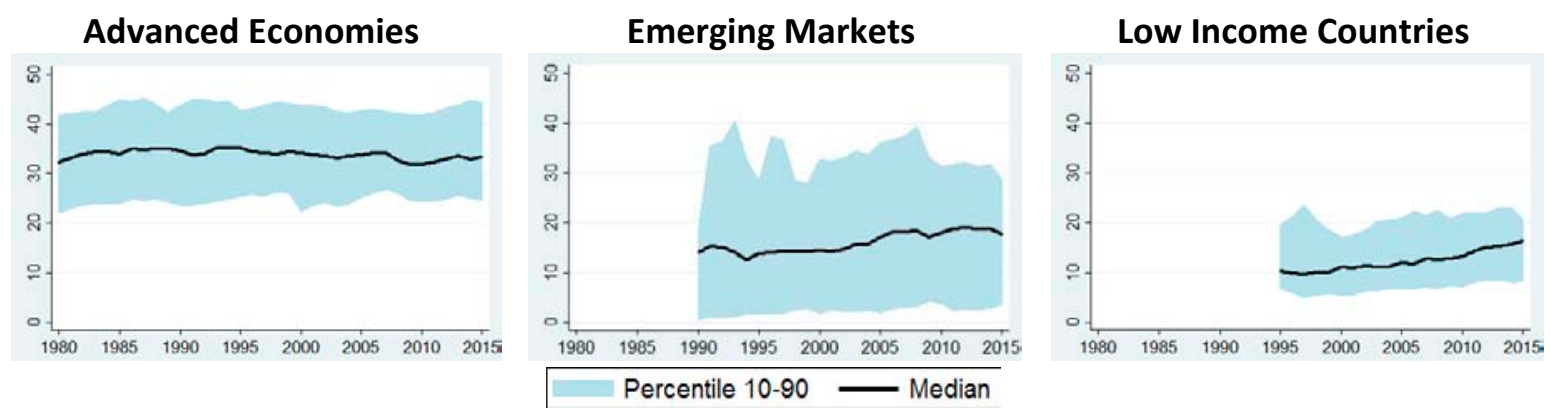

Note: each panel plots the median together with the first and third quartile. Source: authors' calculations

Table 1. Summary Statistics

\begin{tabular}{cl|ccccc}
\hline & Tot. Rev. & PIT & CIT & TGS & SSC \\
\hline \multirow{2}{*}{ AEs } & Mean & 33.8 & 9.5 & 2.9 & 10.5 & 8.6 \\
& Diff. last minus first 5 years & 2.6 & -0.2 & 0.7 & -0.1 & 1.1 \\
\multirow{2}{*}{ EMEs } & Mean & 17.3 & 2.7 & 3.0 & 8.4 & 3.7 \\
& Diff. last minus first 5 years & 2.1 & 0.1 & 1.1 & 1.4 & 0.7 \\
& Mean & 13.4 & 1.9 & 2.2 & 5.8 & 1.1 \\
& Diff. last minus first 5 years & 3.2 & 0.7 & 0.6 & 2.0 & 0.2 \\
\hline
\end{tabular}

Source: authors' calculations

\section{Time Series Regressions}

We start by estimating the parameters of equation (3) country-by-country. For each country the natural logarithm of the tax revenue (and its components) and the natural logarithm of GDP are non-stationary, and cointegrated. We estimate the long-run tax buoyancy in

\footnotetext{
${ }^{7}$ For other tax categories, namely PIT, CIT, TGS and SSC, interquartile plots are available from the authors upon request.
} 
equation (2) for total revenue and, separately, for each type of revenue by FMOLS (allowing for a linear trend), and we then estimate the short-run tax buoyancy in equation (3) by OLS, using the residuals from the long-run estimated equation, and setting $p$ and $q$ equal to one for all countries. For each country and revenue type, we test the null hypothesis that the long-run coefficient is equal to one, and, in case of rejection, we test whether it is greater or smaller than one. Country specific results are presented in Appendix 1 (Tables A1a, A1b, and A1c).

On average, the long-run buoyancies of total revenue are slightly greater than one: 1.06 for advanced economies, and 1.15 for both emerging markets and low-income countries. Also, estimates of tax buoyancies are more narrowly distributed for advanced economies than for the other two groups of countries, possibly owing to fewer observations (see Figure 2 and Table 2). However, these averages and distributions mask a large amount of country specific heterogeneity and do not tell much about whether the long-run tax buoyancy is significantly different from one at the country level. Indeed, for the majority of countries within each country group, we cannot reject the hypothesis that the long-run elasticity is equal to one

We find a similar pattern for the different revenue categories. The long-run buoyancies of the PIT, TGS, and SSC are only slightly greater than one on average, but they are not significantly different from one in the majority of countries within each group. Also, the dispersion of estimates is generally between 0.2 and 0.4 for all country groups and revenue types. The CIT represents an exception. Although it is on average largely greater than one, for the majority of countries within each group we cannot reject the hypothesis that it is equal to one, suggesting that, for some countries, it is significantly greater than one by a large margin.

The average short-run tax buoyancy is between 0.96 and 1.2 in the three groups of countries (Figure 3 and Table 3). Short-run buoyancy is not significantly different from one in the majority of countries within each country group, suggesting that tax systems are mostly neither good nor bad output stabilizers. Instead, the CIT is on average largely greater than one, and it is significantly greater than one in about half of the countries within each country group, suggesting that the CIT contributes to stabilize output over the cycle. Estimates of short-run tax buoyancy show similar variation to estimates of long-run tax buoyancy in advanced economies but somewhat higher variation in emerging and low income countries. Finally, the speed of adjustment is generally negative for most countries, a fact consistent with convergence to a long-run relationship. 
Figure 2. Kernel Density of FMOLS Estimates of Long-Run Buoyancies
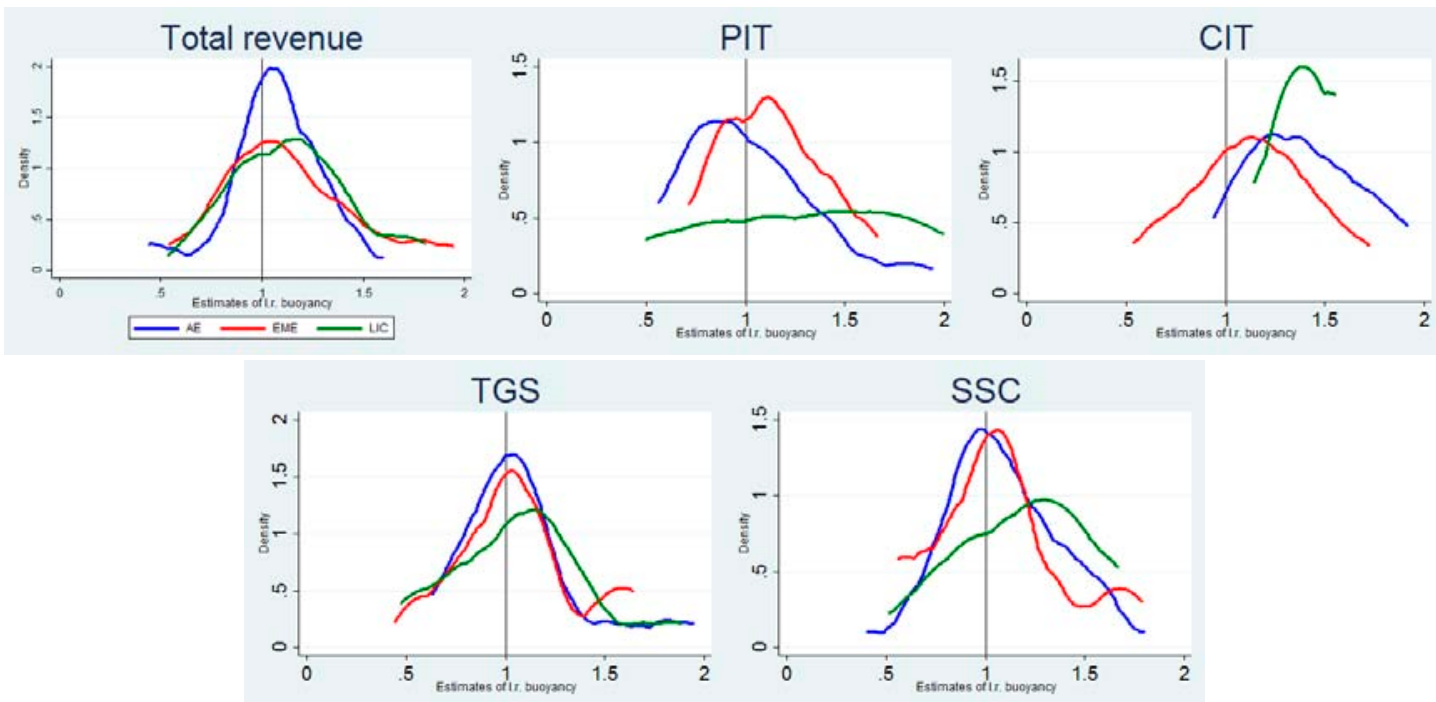

Table 2. Summary Statistics of FMOLS Estimates of Long-Run Buoyancies

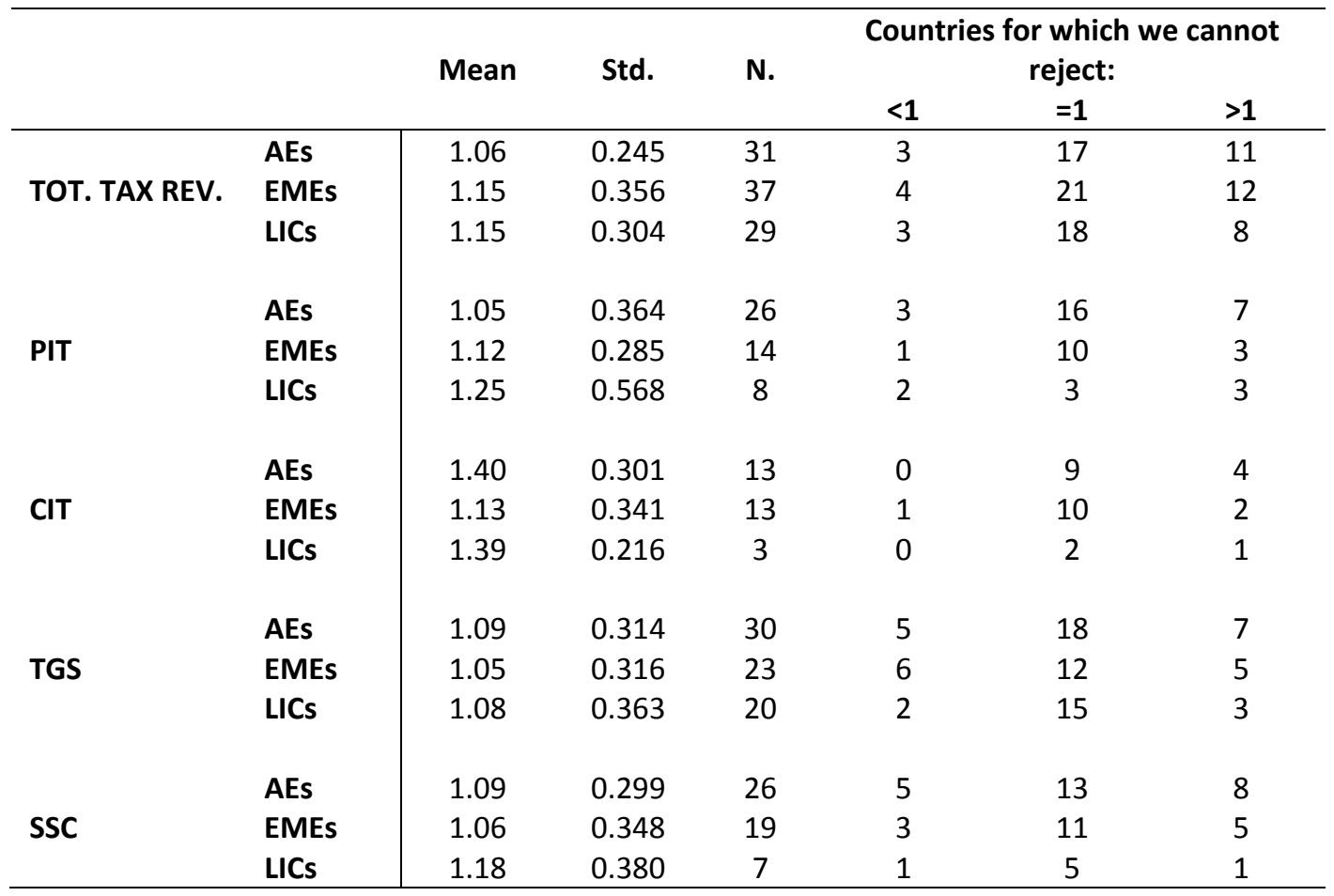

Note: Each country group covers a different time span. More specifically, while for AEs data exists since the 1980s, for EMEs and LICs it exists only from the 1990s. It excludes estimates that are not significantly different from zero and outliers. 
Figure 3. Kernel Density of FMOLS Estimates of Short-Run Buoyancies

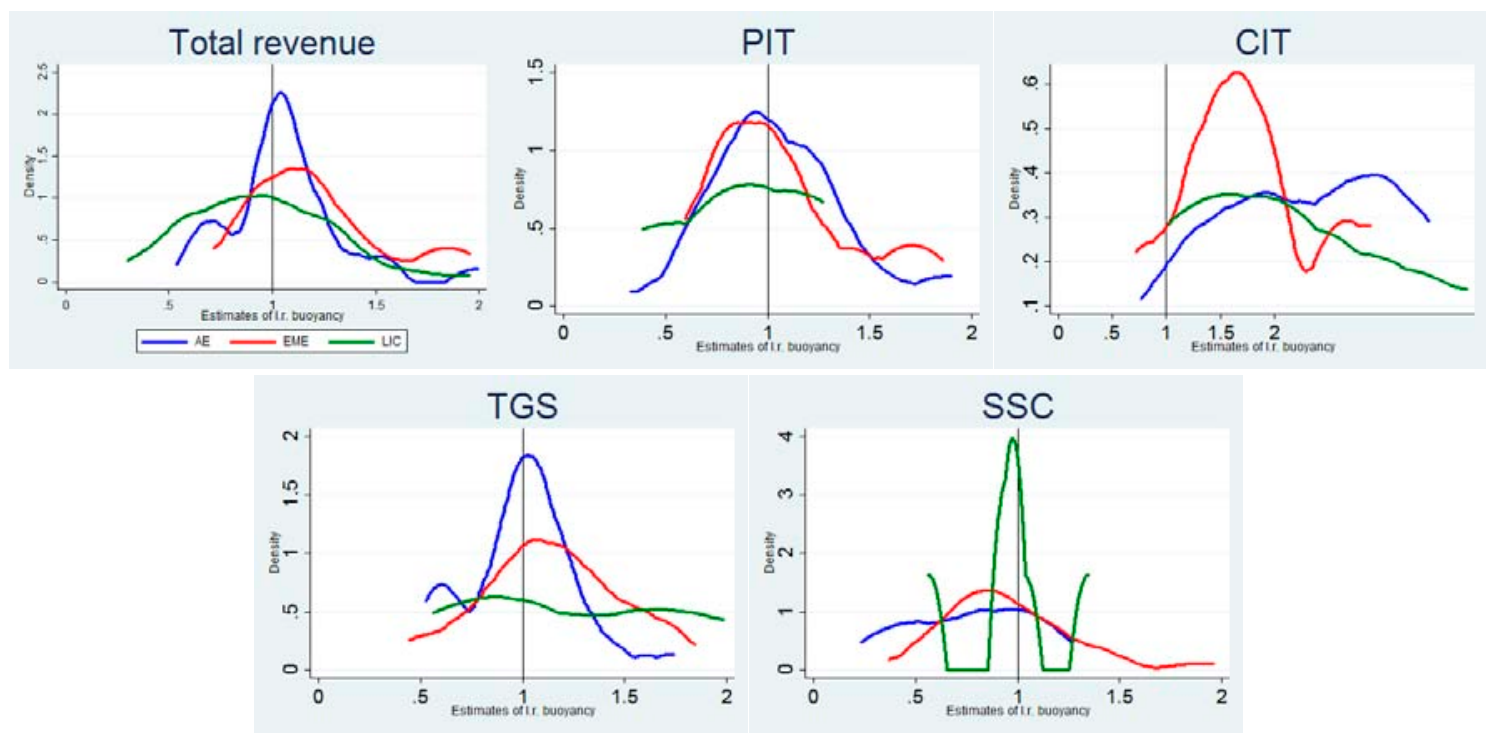

Table 3. Summary Statistics of FMOLS Estimates of Short-Run Buoyancies

\begin{tabular}{|c|c|c|c|c|c|c|c|}
\hline & & \multirow{2}{*}{ Mean } & \multirow{2}{*}{ Std. } & \multirow{2}{*}{$\mathbf{N}$. } & \multicolumn{3}{|c|}{ Countries for which we cannot reject: } \\
\hline & & & & & $<1$ & $=1$ & $>1$ \\
\hline \multirow{3}{*}{ TOT. TAX REV. } & AEs & 1.06 & 0.285 & 31 & 3 & 22 & 6 \\
\hline & EMEs & 1.21 & 0.338 & 31 & 1 & 21 & 9 \\
\hline & LICs & 0.96 & 0.368 & 24 & 7 & 16 & 1 \\
\hline \multirow{3}{*}{ PIT } & AEs & 1.06 & 0.354 & 25 & 1 & 22 & 2 \\
\hline & EMEs & 1.09 & 0.401 & 9 & 1 & 8 & 0 \\
\hline & LICs & 0.91 & 0.427 & 4 & 1 & 3 & 0 \\
\hline \multirow{3}{*}{ CIT } & AEs & 2.33 & 0.814 & 19 & 0 & 11 & 8 \\
\hline & EMEs & 1.79 & 0.720 & 13 & 0 & 8 & 5 \\
\hline & LICs & 2.12 & 1.011 & 7 & 0 & 4 & 3 \\
\hline \multirow{3}{*}{ TGS } & AEs & 1.00 & 0.276 & 29 & 4 & 22 & 3 \\
\hline & EMEs & 1.14 & 0.357 & 24 & 3 & 18 & 3 \\
\hline & LICs & 1.24 & 0.522 & 15 & 2 & 10 & 3 \\
\hline \multirow{3}{*}{ SSC } & AEs & 0.76 & 0.313 & 25 & 12 & 12 & 1 \\
\hline & EMEs & 0.96 & 0.345 & 19 & 5 & 12 & 2 \\
\hline & LICs & 0.97 & 0.279 & 5 & 1 & 4 & 0 \\
\hline
\end{tabular}

Note: Each country group covers a different time span. More specifically, while for AEs data exists since the 1980s, for EMEs and LICs it exists only from the 1990s. It excludes estimates that are not significantly different from zero and outliers.

In those countries where we cannot reject the hypothesis that the long-run buoyancy be equal to one, we explore how short-run buoyancy estimates change if we impose this restriction. As one might expect, short-run tax buoyancy estimates do not change in a significant way; for each country group and revenue category, the correlation coefficient between short-run tax buoyancy estimates with and those without the restriction is generally above 95 percent.

These findings (in particular, the fact that restrictions on long-run buoyancy do not seem to affect estimates of short-run tax buoyancies) give us comfort that the homogeneity restrictions imposed by the PMG estimators would not result into a large estimator bias. 


\section{Panel Regression}

We then estimate equation (3) for each of the three country groups by panel techniques, using data for total tax revenue across the entire time span under scrutiny. First, we conduct panel stationarity tests. Results of first (Im-Pesaran-Shin, 1997; Maddala-Wu, 1999) and second generation (Pesaran CIPS, 2007) panel integration tests are presented in Appendix 1 (Tables A2 and A3). We cannot reject the null hypothesis that variables are nonstationarity. In estimating equation (3) we assume that the long-run relationship is composed of a countryspecific level and a set of common factors, and that factor loadings are country-specific.

Table 4 shows the estimated coefficients for short-run, long-run and the speed of adjustment using either a MG (including a variant where we constrain the long-run coefficient to be one) or a PMG estimator. ${ }^{8}$ Consistent with what we find on a country-by-country basis, results suggest that for advanced economies, on average, both long-run and short-run tax buoyancies are not statistically different from one. In emerging markets and low income countries, however, while long-run tax buoyancy is generally not statistically different from one, the short-run coefficient is generally statistically larger than one.

Table 4. Overall Tax Buoyancy by Country Group, Alternative Estimators

\begin{tabular}{|c|c|c|c|c|c|c|c|c|c|}
\hline Country group & \multicolumn{3}{|c|}{$A E$} & \multicolumn{3}{|c|}{$E M E$} & \multicolumn{3}{|c|}{$L I C$} \\
\hline Estimator & MG & $\begin{array}{c}\mathrm{MG} \\
\text { (constraint) }\end{array}$ & PMG & MG & $\begin{array}{c}\mathrm{MG} \\
\text { (constraint) }\end{array}$ & PMG & MG & $\begin{array}{c}\mathrm{MG} \\
\text { (constraint) }\end{array}$ & PMG \\
\hline $\begin{array}{l}\text { Long run } \\
\text { buoyancy }\end{array}$ & $\begin{array}{c}\mathbf{0 . 9 9 7} * * * \\
(0.024)\end{array}$ & $\begin{array}{c}1.000 \\
(0.000)\end{array}$ & $\begin{array}{c}\mathbf{1 . 0 0 0 * * *} \\
(0.008)\end{array}$ & $\begin{array}{c}\mathbf{1 . 0 6 0 * * *} \\
(0.039)\end{array}$ & $\begin{array}{c}1.000 \\
(0.000)\end{array}$ & $\begin{array}{c}1.070 * * * \\
(0.006)\end{array}$ & $\begin{array}{c}1.210 * * * \\
(0.061)\end{array}$ & $\begin{array}{c}1.000 \\
(0.000)\end{array}$ & $\begin{array}{c}\mathbf{1 . 2 0 1} * * * \\
(0.012)\end{array}$ \\
\hline $\begin{array}{l}\text { Short run } \\
\text { buoyancy }\end{array}$ & $\begin{array}{c}\mathbf{1 . 0 1 0} \text { *** } \\
(0.071)\end{array}$ & $\begin{array}{c}\text { 1.015*** } \\
(0.054)\end{array}$ & $\begin{array}{c}\mathbf{0 . 9 7 5} * * * \\
(0.053)\end{array}$ & $\begin{array}{c}1.235 * * * \\
(0.090)\end{array}$ & $\begin{array}{c}1.221 * * * \\
(0.090)\end{array}$ & $\begin{array}{c}1.214 * * * \\
(0.091)\end{array}$ & $\begin{array}{c}1.200 * * * \\
(0.172)\end{array}$ & $\begin{array}{c}\mathbf{0 . 8 3 9} * * * \\
(0.136)\end{array}$ & $\begin{array}{c}1.196 * * * \\
(0.164)\end{array}$ \\
\hline $\begin{array}{c}\text { Speed of } \\
\text { adjustment }\end{array}$ & $\begin{array}{c}-0.355^{* * *} * \\
(0.034)\end{array}$ & $\begin{array}{c}-0.356 * * * \\
(0.033)\end{array}$ & $\begin{array}{c}-0.236 * * * \\
(0.025)\end{array}$ & $\begin{array}{c}-0.489 * * * \\
(0.041)\end{array}$ & $\begin{array}{c}-0.470 * * * \\
(0.039)\end{array}$ & $\begin{array}{c}-0.339 * * * \\
(0.033)\end{array}$ & $\begin{array}{c}-0.525 * * * \\
(0.046)\end{array}$ & $\begin{array}{c}-0.530 * * * \\
(0.046)\end{array}$ & $\begin{array}{c}-0.325 * * * \\
(0.037)\end{array}$ \\
\hline Observations & 922 & 922 & 922 & 726 & 726 & 726 & 716 & 716 & 716 \\
\hline \# Countries & 31 & 31 & 31 & 38 & 38 & 38 & 38 & 38 & 38 \\
\hline
\end{tabular}

Note: The "constraint" version of the MG estimator imposes a unitary long-run coefficient. Bold italic means statistically greater than one at 5 percent level; bold means statistically not different from one at 5 percent level. Standard errors in parenthesis. ${ }^{*}, * * * * *$ denote statistical significance at the 10,5 and 1 percent levels, respectively.

Differences in tax buoyancy across country groups may reflect developments in revenue categories. In fact, changes in the tax mix from more to less buoyant taxes (or vice-versa) can modify the buoyancy of aggregate revenue. Table 5 shows the results of panel regressions for each of the four tax categories, based on the PMG estimator:

- $\quad$ Long-run tax buoyancy is found to exceed one in the case of CIT for advanced economies, PIT and SSC in emerging markets, and TGS for low income countries. In advanced economies, the high long-run buoyancy of the CIT may reflect the gradual

\footnotetext{
${ }^{8}$ We used the BIC test to choose the optimal lag length for $p$ and $q$, which was found to be equal to 1 for both.
} 
decline in the labor-income share over the recent decades. This also explains the relatively low buoyancy of the PIT, which is significantly lower than one.

- Short-run buoyancy is also significantly larger than one in the case of CIT for advanced economies, but also in emerging markets, suggesting that, relative to other taxes, it has been so far the best source of output stabilization in these groups of countries. In advanced economies, interestingly, short run buoyancy of SSC is significantly smaller than one possibly due to their regressive structure.

Table 5. Buoyancy of Tax Revenue Components

\begin{tabular}{|c|c|c|c|c|}
\hline$A E$ & PIT & CIT & TGS & $S S C$ \\
\hline Long run buoyancy & $\begin{array}{c}0.907 * * * \\
(0.015)\end{array}$ & $\begin{array}{c}1.516 * * * \\
(0.034)\end{array}$ & $\begin{array}{c}0.951 * * * \\
(0.008)\end{array}$ & $\begin{array}{c}0.941 * * * \\
(0.009)\end{array}$ \\
\hline Short run buoyancy & $\begin{array}{c}\mathbf{0 . 7 9 8 * * *} \\
(0.110)\end{array}$ & $\begin{array}{c}2.936 * * * \\
(0.240)\end{array}$ & $\begin{array}{c}0.873 * * * \\
(0.051)\end{array}$ & $\begin{array}{c}0.600^{* * * *} \\
(0.102)\end{array}$ \\
\hline Speed of adjustment & $\begin{array}{c}-0.249 * * * \\
(0.026)\end{array}$ & $\begin{array}{c}-0.344 * * * \\
(0.034)\end{array}$ & $\begin{array}{c}-0.256^{* * *} \\
(0.034)\end{array}$ & $\begin{array}{c}-0.251 * * * \\
(0.036)\end{array}$ \\
\hline $\begin{array}{r}\text { Observations } \\
\text { \# Countries }\end{array}$ & $\begin{array}{c}873 \\
29 \\
\end{array}$ & $\begin{array}{c}873 \\
29 \\
\end{array}$ & $\begin{array}{c}900 \\
30 \\
\end{array}$ & $\begin{array}{c}834 \\
27 \\
\end{array}$ \\
\hline$E M E$ & PIT & CIT & TGS & SSC \\
\hline Long run buoyancy & $\begin{array}{c}1.036 * * * \\
(0.016)\end{array}$ & $\begin{array}{c}1.014 * * * \\
(0.011)\end{array}$ & $\begin{array}{c}1.000 * * * \\
(0.009)\end{array}$ & $\begin{array}{c}1.668 * * * \\
(0.029)\end{array}$ \\
\hline Short run buoyancy & $\begin{array}{c}1.211 * * * \\
(0.204)\end{array}$ & $\begin{array}{c}1.590 * * * \\
(0.272)\end{array}$ & $\begin{array}{c}1.027 * * * \\
(0.120)\end{array}$ & $\begin{array}{c}1.210 * * * \\
(0.272)\end{array}$ \\
\hline Speed of adjustment & $\begin{array}{c}-0.407 * * * \\
(0.062)\end{array}$ & $\begin{array}{c}-0.379 * * * \\
(0.054)\end{array}$ & $\begin{array}{c}-0.359^{* * *} \\
(0.047)\end{array}$ & $\begin{array}{l}-0.024 \\
(0.210)\end{array}$ \\
\hline $\begin{array}{r}\text { Observations } \\
\text { \# Countries } \\
\end{array}$ & $\begin{array}{c}368 \\
22 \\
\end{array}$ & $\begin{array}{c}442 \\
25 \\
\end{array}$ & $\begin{array}{c}500 \\
28 \\
\end{array}$ & $\begin{array}{c}461 \\
25 \\
\end{array}$ \\
\hline$L I C$ & PIT & CIT & TGS & $\mathrm{SSC}$ \\
\hline Long run buoyancy & $\begin{array}{c}0.487 * * * \\
(0.043)\end{array}$ & $\begin{array}{c}0.887 * * * \\
(0.048)\end{array}$ & $\begin{array}{c}1.075 * * * \\
(0.013)\end{array}$ & $\begin{array}{c}\mathbf{1 . 0 2 4} * * * \\
(0.034)\end{array}$ \\
\hline Short run buoyancy & $\begin{array}{r}\mathbf{0 . 9 3 2} * * \\
(0.470)\end{array}$ & $\begin{array}{c}1.491 * * * \\
(0.493)\end{array}$ & $\begin{array}{c}\mathbf{1 . 0 3 0} * * * \\
(0.211)\end{array}$ & $\begin{array}{c}1.041 \\
(0.929)\end{array}$ \\
\hline Speed of adjustment & $\begin{array}{c}-0.162 * * \\
(0.063)\end{array}$ & $\begin{array}{c}-0.251 * * * \\
(0.056)\end{array}$ & $\begin{array}{c}-0.353 * * * \\
(0.035)\end{array}$ & $\begin{array}{c}-0.416^{* * * *} \\
(0.087)\end{array}$ \\
\hline $\begin{array}{c}\text { Observations } \\
\text { \# Countries }\end{array}$ & $\begin{array}{c}261 \\
17\end{array}$ & $\begin{array}{c}259 \\
17\end{array}$ & $\begin{array}{c}582 \\
32\end{array}$ & $\begin{array}{c}122 \\
7\end{array}$ \\
\hline
\end{tabular}

Note: Estimation of Equation (3) by PMG estimator (see main text for details). Bold italic means statistically greater than one at 5 percent level; bold means statistically not different from one at 5 percent level. Standard errors in parenthesis. ${ }^{*}, * *, * *$ denote statistical significance at the 10,5 and 1 percent levels, respectively.

\section{E. Robustness Checks and Estimates of Elasticity}

If tax policy parameters (for example, tax rates, tax base, exemptions) are correlated with changes in GDP, then there could exist a divergence between buoyancy and elasticity estimates. An accurate estimate of elasticity, which would actually more appropriately capture the automatic stabilization role of revenues, requires controlling for as many tax policy parameters as possible. Lacking the necessary data, we gauge how different elasticities and buoyancies could be by controlling only for tax rates in equation (3). This is important in light 
of tax reforms enacted since the 1980s in several countries. Given the limited coverage of the tax rates dataset, the sample period and country coverage is somewhat reduced in this exercise. We use PIT rates in the PIT regression, CIT rates in the CIT regression, and Value Added or Sales Tax rates (VAT/TGS) in the TGS regression. Results for both regressions including and excluding tax rates as a control are displayed in Table 6.

Table 6. Buoyancy of PIT, CIT and TGS with and without Controlling for Tax Rates

\begin{tabular}{|c|c|c|c|c|c|c|}
\hline \multirow{2}{*}{$\begin{array}{l}\text { Country group } \\
\text { PIT } \\
\text { (PIT rate) }\end{array}$} & \multicolumn{2}{|c|}{$A E$} & \multicolumn{2}{|c|}{$E M E$} & \multicolumn{2}{|c|}{$L I C$} \\
\hline & $\begin{array}{l}\text { No control } \\
\text { (memory) }\end{array}$ & Control & $\begin{array}{l}\text { No control } \\
\text { (memory) }\end{array}$ & Control & No control & Control \\
\hline Long run buoyancy & $\begin{array}{c}0.907 * * * \\
(0.015)\end{array}$ & $\begin{array}{c}0.966^{* * *} \\
(0.014)\end{array}$ & $\begin{array}{c}1.036 * * * \\
(0.016)\end{array}$ & $\begin{array}{c}1.004 * * * \\
(0.012)\end{array}$ & $\begin{array}{l}- \\
-\end{array}$ & $\begin{array}{l}- \\
-\end{array}$ \\
\hline Short run buoyancy & $\begin{array}{c}\mathbf{0 . 7 9 8} * * * \\
(0.110)\end{array}$ & $\begin{array}{c}\mathbf{0 . 9 7 4} * * * \\
(0.135)\end{array}$ & $\begin{array}{c}1.211 * * * \\
(0.204)\end{array}$ & $\begin{array}{c}1.048 * * * \\
(0.373)\end{array}$ & - & - \\
\hline $\begin{array}{r}\text { Speed of Adjustment } \\
\text { Observations }\end{array}$ & $\begin{array}{c}-0.249 * * * \\
(0.026) \\
873\end{array}$ & $\begin{array}{c}-0.379 * * * \\
(0.053) \\
666\end{array}$ & $\begin{array}{c}-0.407 * * * \\
(0.062) \\
368\end{array}$ & $\begin{array}{c}-0.446 * * * \\
(0.083) \\
328\end{array}$ & $\begin{array}{l}- \\
-\end{array}$ & $\begin{array}{l}- \\
- \\
-\end{array}$ \\
\hline $\begin{array}{c}\text { CIT } \\
\text { (CIT rate) }\end{array}$ & $\begin{array}{l}\text { No control } \\
\text { (memory) }\end{array}$ & Control & $\begin{array}{c}\text { No control } \\
\text { (memory) }\end{array}$ & Control & $\begin{array}{l}\text { No control } \\
\text { (memory) }\end{array}$ & Control \\
\hline Long run buoyancy & $\begin{array}{l}1.516 * * * \\
(0.034)\end{array}$ & $\begin{array}{c}1.585 * * * \\
(0.047)\end{array}$ & $\begin{array}{c}1.014 * * * \\
(0.011)\end{array}$ & $\begin{array}{c}1.143 * * * \\
(0.029)\end{array}$ & $\begin{array}{c}0.887 * * * \\
(0.048)\end{array}$ & $\begin{array}{c}1.521 * * * \\
(0.041)\end{array}$ \\
\hline Short run buoyancy & $\begin{array}{c}2.936 * * * \\
(0.240)\end{array}$ & $\begin{array}{c}3.611 * * * \\
(0.399)\end{array}$ & $\begin{array}{c}1.590 * * * \\
(0.272)\end{array}$ & $\begin{array}{c}1.715 * * * \\
(0.280)\end{array}$ & $\begin{array}{c}1.491 * * * \\
(0.493)\end{array}$ & $\begin{array}{c}1.241 * * * \\
(0.333)\end{array}$ \\
\hline $\begin{array}{r}\text { Speed of Adjustment } \\
\text { Observations }\end{array}$ & $\begin{array}{c}-0.344 * * * \\
(0.034) \\
873\end{array}$ & $\begin{array}{c}-0.483 * * * \\
(0.031) \\
666\end{array}$ & $\begin{array}{c}-0.379 * * * \\
(0.054) \\
441\end{array}$ & $\begin{array}{c}-0.393 * * * \\
(0.049) \\
412\end{array}$ & $\begin{array}{c}-0.251 * * * \\
(0.056) \\
259\end{array}$ & $\begin{array}{c}-0.604^{* * *} \\
(0.088) \\
212\end{array}$ \\
\hline $\begin{array}{c}\text { TGS } \\
\text { (VAT rate) }\end{array}$ & $\begin{array}{l}\text { No control } \\
\text { (memory) }\end{array}$ & Control & $\begin{array}{c}\text { No control } \\
\text { (memory) }\end{array}$ & Control & $\begin{array}{c}\text { No control } \\
\text { (memory) }\end{array}$ & Control \\
\hline Long run buoyancy & $\begin{array}{c}0.951 * * * \\
(0.008)\end{array}$ & $\begin{array}{c}0.867 * * * \\
(0.012)\end{array}$ & $\begin{array}{l}- \\
-\end{array}$ & $\begin{array}{l}- \\
-\end{array}$ & $\begin{array}{l}- \\
-\end{array}$ & $\begin{array}{l}- \\
-\end{array}$ \\
\hline Short run buoyancy & $\begin{array}{c}0.873 * * * \\
(0.051)\end{array}$ & $\begin{array}{c}\mathbf{0 . 8 9 0} * * * \\
(0.104)\end{array}$ & $\begin{array}{l}- \\
-\end{array}$ & $\begin{array}{l}- \\
-\end{array}$ & $\begin{array}{l}- \\
-\end{array}$ & $\begin{array}{l}- \\
-\end{array}$ \\
\hline Speed of Adjustment & $\begin{array}{c}-0.256^{* * * *} \\
(0.034)\end{array}$ & $\begin{array}{c}-0.459 * * * \\
(0.050)\end{array}$ & $\begin{array}{l}- \\
-\end{array}$ & $\begin{array}{l}- \\
-\end{array}$ & $\begin{array}{l}- \\
-\end{array}$ & $\begin{array}{l}- \\
-\end{array}$ \\
\hline Observations & 900 & 547 & - & - & - & - \\
\hline
\end{tabular}

Note: Estimation of Equation (3) by PMG estimator (see main text for details) for three tax components identified in column 1: personal income tax, corporate income tax and taxes on goods and services. Bold italic means statistically greater than one at 5 percent level; bold means statistically not different from one at 5 percent level. Standard errors in parenthesis. ${ }^{*}, * * * * *$ denote statistical significance at the 10, 5 and 1 percent levels, respectively.

Most estimates of buoyancy increase after controlling for tax rates. Specifically, controlling for the top PIT rate yields significantly higher long-run tax buoyancy for advanced economies than without controlling for the top PIT rate. Hence, adjustments in PIT rates might have been correlated with GDP. For emerging markets there isn't any difference. For the CIT, both short and long-run buoyancy are significantly larger than one and generally higher in magnitude when controlling for CIT rates. Finally, for the TGS the short-run buoyancy now yields a coefficient not statistically different from one when controlling for inflation, whereas previously it was statistically smaller. We also controlled for square of the tax rate, to control for the possibility that the response of revenues to GDP differs for different level of tax rates. We found no evidence that this is the case. 
A second robustness check tackles the issue that when estimating equation (3), in which we use nominal changes in both tax revenues and GDP, we include both a price component and a real component. Adding inflation as an additional control is important to assess whether tax buoyancy is independent or not from price developments. If the latter, the same relationship would be obtained if real variables were used instead. Results in Table 7 show that inflation enters with a significant positive coefficient, particularly in the long-run. Moreover, the coefficients for buoyancy are now smaller than before. Hence, tax buoyancy does not appear neutral with respect to inflation, meaning that tax buoyancy in real terms is smaller than in nominal terms.

Table 7. Overall Tax Buoyancy with and without Controlling for Inflation

\begin{tabular}{|c|c|c|c|c|c|c|}
\hline \multirow{2}{*}{$\begin{array}{r}\text { Country group } \\
\text { Specification }\end{array}$} & \multicolumn{2}{|r|}{$A E$} & \multicolumn{2}{|c|}{$E M E$} & \multicolumn{2}{|c|}{$L I C$} \\
\hline & $\begin{array}{l}\text { No control } \\
\text { for inflation }\end{array}$ & $\begin{array}{l}\text { Control for } \\
\text { inflation }\end{array}$ & $\begin{array}{l}\text { No control } \\
\text { for inflation }\end{array}$ & $\begin{array}{l}\text { Control for } \\
\text { inflation }\end{array}$ & $\begin{array}{l}\text { No control } \\
\text { for inflation }\end{array}$ & $\begin{array}{l}\text { Control for } \\
\text { inflation }\end{array}$ \\
\hline \multirow{2}{*}{$\begin{array}{l}\text { Long run } \\
\text { buoyancy }\end{array}$} & $1.000 * * *$ & $0.996^{* * * *}$ & $1.070^{* * * *}$ & $1.073 * * *$ & $1.201 * * *$ & $1.188 * * *$ \\
\hline & $(0.008)$ & (0.009) & $(0.006)$ & $(0.007)$ & $(0.012)$ & $(0.011)$ \\
\hline \multirow{2}{*}{$\begin{array}{l}\text { Short run } \\
\text { buoyancy }\end{array}$} & $0.975^{* * *}$ & $0.992 * * *$ & $1.214^{* * *}$ & $1.289 * * *$ & $1.196 * * *$ & $1.213^{* * * *}$ \\
\hline & $(0.053)$ & $(0.051)$ & $(0.091)$ & $(0.106)$ & $(0.164)$ & $(0.186)$ \\
\hline \multirow[t]{2}{*}{$\begin{array}{l}\text { Long run } \\
\text { price effect }\end{array}$} & & $0.493 * * *$ & & $0.821 * * *$ & & $0.323^{*}$ \\
\hline & & $(0.146)$ & & $(0.144)$ & & $(0.192)$ \\
\hline \multirow[t]{2}{*}{$\begin{array}{l}\text { Short run } \\
\text { price effect }\end{array}$} & & 0.009 & & 0.140 & & 0.063 \\
\hline & & (0.064) & & $(0.278)$ & & $(0.124)$ \\
\hline \multirow{2}{*}{$\begin{array}{l}\text { Speed of } \\
\text { adjustment }\end{array}$} & $-0.236^{* * *}$ & $-0.255^{* * *}$ & $-0.339 * * *$ & $-0.364 * * *$ & $-0.325^{* * *}$ & $-0.322 * * *$ \\
\hline & $(0.025)$ & $(0.033)$ & $(0.033)$ & $(0.043)$ & $(0.037)$ & $(0.035)$ \\
\hline Observations & 922 & 889 & 726 & 720 & 716 & 713 \\
\hline \# Countries & 31 & 31 & 38 & 38 & 38 & 38 \\
\hline
\end{tabular}

Note: Estimation of Equation (3) by PMG estimator controlling or not controlling for inflation (see main text for details). Bold italic means statistically greater than one at 5 percent level; bold means statistically not different from one at 5 percent level. Standard errors in parenthesis. ${ }^{*}, *, * * *$ denote statistical significance at the 10,5 and 1 percent levels, respectively.

\section{Tax Buoyancy around Business Cycle Turning Points}

After estimating long-run and short-run buoyancy, we explore, in this section, whether the stabilization role of taxation (captured by the short-run buoyancy) has varied during periods of economic expansion and economic contraction. For example, empirical evidence suggests that compliance falls quickly and quite strongly, although for a short time, as output falls below potential. This would imply that the response to revenue to changes in GDP would differ depending on whether output is falling below potential, or increasing above potential (IMF, 2015, and Sancak and others, 2010).

We begin with an event-study type exercise, by plotting the overall tax revenue to GDP ratios by country group around recession episodes (identified as years of negative GDP growth, year $t$ in the graphs of Figure 4, below), as well as one and two years before/after the episode. 
Figure 4. Tax Revenue and Categories Around Recession Episodes (Percent of GDP)

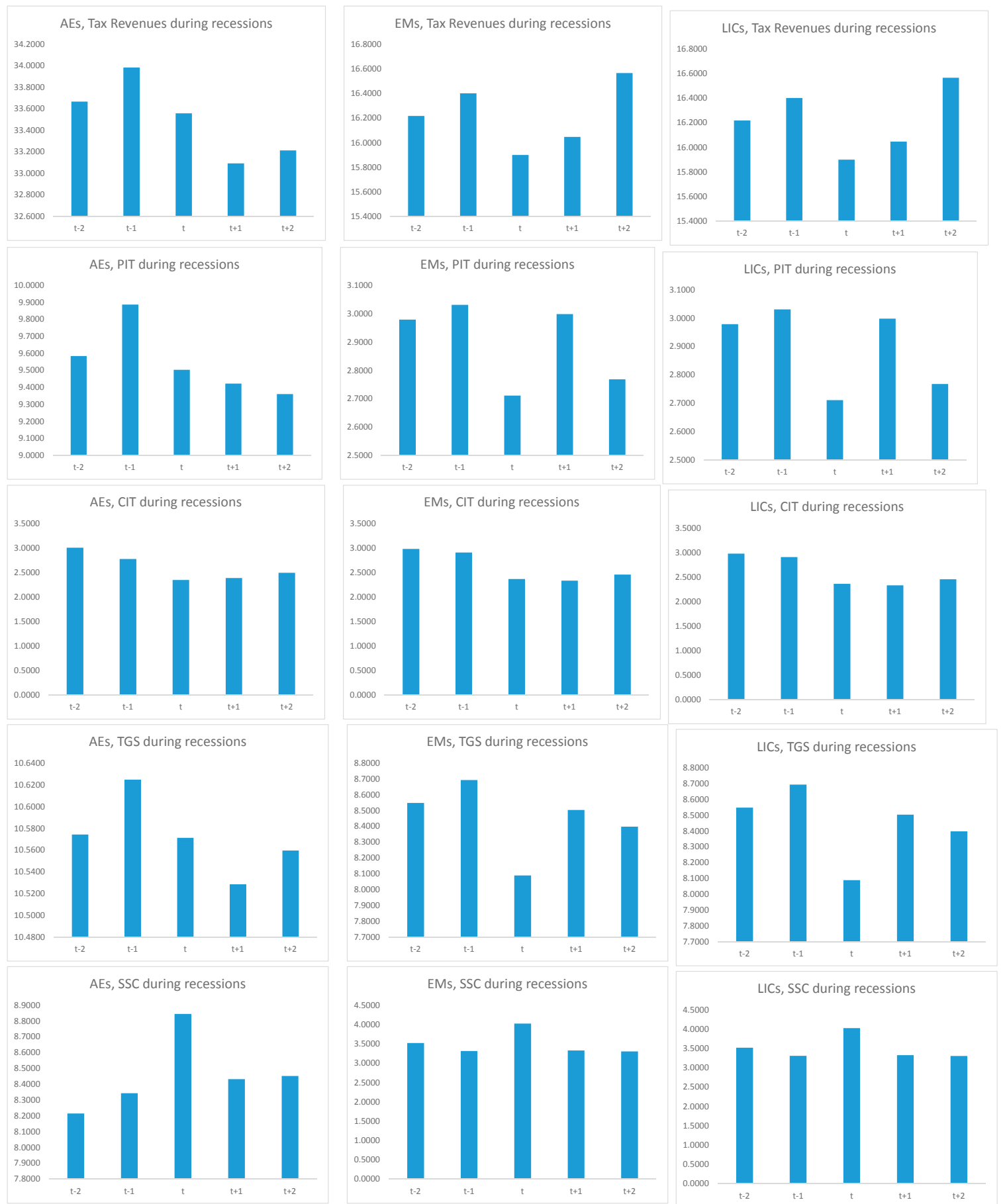

Note: " $t$ " corresponds to the average of the relevant tax revenue over the entire recession episode. " $t+1$ " (" $t+2$ ") correspond to the value of the ratio of the relevant tax revenue to GDP one (two) year after the end of the recession episode. Mutatis mutandis for " $\mathrm{t}-1$ " ("t-2").

Source: authors' calculations. 
The first observation coming out of Figure 3 is that overall tax revenues decrease immediately from $t-1$ to $t$ in all country groups, that is, the short-run buoyancy of tax revenues appears to be greater than one during a recession, suggesting that the tax system have been operating as an output stabilizer in the year of a recession. That said, in emerging and low income countries tax revenues seem to recover immediately in $t+1$, while it generally takes some time for that to materialize in advanced economies, where tax revenues remain subdued for a longer period. Looking at the four different tax categories, such lagged effect in advanced economies can be explained by a lagged and slow recovery in personal income taxes and taxes on goods and services. Social security contributions seem to increase in the year of the recession across all groups.

To further explore whether the tax system is buoyant during recessions, we estimate equation (3) only over 2008-2012, a period commonly identified as associated to the Global Financial Crisis. Results (displayed in Table A4 in the Appendix 1) suggest that, relative to estimates presented in Table 3 , most of the buoyancy estimates (when statistically significant) are higher in magnitude, which indicates that after the Great Recession tax systems behaved slightly more as output stabilizers than on average in normal times. ${ }^{9}$ We also repeat the previous exercise, but now for each tax category for the reduced 2008-2012 period. Evidence (displayed in Table A5 in the Appendix 1) suggests that in advanced economies, PIT and TGS long run buoyancy coefficients are not only larger during the GFC relative to the average value, but they are also significantly larger than one. In the case of short-run buoyancy all taxes saw their contributions as output stabilizers enhanced during the Great Recession, in both AEs and EMEs. For low income countries such contribution came from CIT and TGS.

To formalize the above findings and in order to better explore whether tax buoyancy varies depending on the phase of the business cycle, the following alternative short-run regression is estimated:

$$
\begin{aligned}
& \Delta \ln Y_{i, t}=\alpha_{i}^{k}+\text { Time }_{t}^{k}+\beta_{k}^{\text {contraction }} \cdot Y(z) \cdot \Delta \ln \boldsymbol{X}_{i, t}+\beta_{k}^{\text {expansion }} \cdot(1-Y(z)) \cdot \Delta \ln \boldsymbol{X}_{i, t}+ \\
& \varepsilon_{i, t}^{k}
\end{aligned}
$$

with $Y\left(z_{i t}\right)=\frac{\exp \left(-\gamma z_{i t}\right)}{1+\exp \left(-\gamma z_{i t}\right)}, \quad \gamma>0$

where $z$ is an indicator of the state of the economy (using the real GDP growth rate) normalized to have zero mean and unit variance. The remainder of the variables and coefficients are defined as before. This approach is equivalent to the smooth transition autoregressive (STAR)

\footnotetext{
${ }^{9}$ Using the GFC period to assess tax buoyancy across the business cycle has advantages and disadvantages. On the one hand, the large variations in income may allow for easier identification. On the other, the mix of discretionary policy and automatic stabilizers is unrepresentative: for example, advanced economies used substantially more discretionary fiscal policy during the crisis, with extended post-crisis tax breaks, than they have historically used during regular business cycles. This could lead to over-estimate the response of revenues to a downturn.
} 
model developed by Granger and Teravistra (1993). The main advantage of this approach relative to estimating SVARs for each regime is that it considers a larger number of observations to compute the impulse response functions, thus making the responses more stable and precise.

Table 8 shows that in advanced countries only CIT buoyancy is larger during contractions than during times of economic expansions. Hence, this tax category on average seems to work better as output stabilizer during bad times compared to good times. In emerging market economies, this effect is attributed to both CIT but also to TGS, the buoyancy coefficients of which are found to be statistically larger than one during periods of relatively low growth. Overall, this result is confirmed by Furceri and Jalles (2016) who find that the overall impact of fiscal stabilization (measured as the amount of counter-cyclicality) is larger during recessionary periods.

Table 8. Asymmetric Short-term Buoyancy over the Business Cycle

\begin{tabular}{|c|c|c|c|c|c|c|}
\hline \multirow{2}{*}{$\begin{array}{l}\text { Country group } \\
\text { Type of revenue }\end{array}$} & \multicolumn{2}{|c|}{$A E$} & \multicolumn{2}{|c|}{$E M E$} & \multicolumn{2}{|c|}{$L I C$} \\
\hline & Expansion & Contraction & Expansion & Contraction & Expansion & Contraction \\
\hline Tax revenue & $\begin{array}{c}1.087 * * * \\
(0.050)\end{array}$ & $\begin{array}{c}\mathbf{0 . 9 5 0 * * *} \\
(0.051)\end{array}$ & $\begin{array}{l}1.213 * * * \\
(0.075)\end{array}$ & $\begin{array}{c}1.183 * * * \\
(0.080)\end{array}$ & $\begin{array}{c}\mathbf{1 . 4 8 5 * * *} \\
(0.249)\end{array}$ & $\begin{array}{c}\mathbf{0 . 6 5 2} * * * \\
(0.182)\end{array}$ \\
\hline PIT & $\begin{array}{c}1.092 * * * \\
(0.097)\end{array}$ & $\begin{array}{c}\mathbf{0 . 8 2 3} * * * \\
(0.101)\end{array}$ & $\begin{array}{c}1.051 * * * \\
(0.176)\end{array}$ & $\begin{array}{c}\mathbf{0 . 6 5 0} * * * \\
(0.231)\end{array}$ & $\begin{array}{l}1.415 * * \\
(0.604)\end{array}$ & $\begin{array}{c}0.369 \\
(0.389)\end{array}$ \\
\hline CIT & $\begin{array}{c}1.096 * * * \\
(0.293)\end{array}$ & $\begin{array}{c}2.038 * * * \\
(0.305)\end{array}$ & $\begin{array}{c}\mathbf{0 . 8 8 6} * * * \\
(0.244)\end{array}$ & $\begin{array}{c}2.348 * * * \\
(0.321)\end{array}$ & $\begin{array}{l}-0.128 \\
(1.825)\end{array}$ & $\begin{array}{c}1.572 \\
(1.176)\end{array}$ \\
\hline$T G S$ & $\begin{array}{c}\mathbf{1 . 0 1 8}^{* * * *} \\
(0.068)\end{array}$ & $\begin{array}{c}\mathbf{0 . 9 7 6 * * *} \\
(0.069)\end{array}$ & $\begin{array}{c}0.754 * * * \\
(0.109)\end{array}$ & $\begin{array}{c}1.253 * * * \\
(0.123)\end{array}$ & $\begin{array}{c}1.802 * * * \\
(0.474)\end{array}$ & $\begin{array}{c}0.420 \\
(0.347)\end{array}$ \\
\hline$S S C$ & $\begin{array}{c}\mathbf{0 . 9 5 5} * * * \\
(0.122)\end{array}$ & $\begin{array}{c}\mathbf{0 . 8 8 0} * * * \\
(0.122)\end{array}$ & $\begin{array}{c}1.183 * * * \\
(0.187)\end{array}$ & $\begin{array}{c}\mathbf{0 . 8 0 7 * * *} \\
(0.204)\end{array}$ & $\begin{array}{c}0.585 \\
(0.375)\end{array}$ & $\begin{array}{c}0.224 \\
(0.261)\end{array}$ \\
\hline
\end{tabular}

Note: Estimation of Equation (4) by PMG estimator (see main text for details). Bold italic means statistically greater than one at 5 percent level; bold means statistically not different from one at 5 percent level. Standard errors in parenthesis. *, **, *** denote statistical significance at the 10,5 and 1 percent levels, respectively.

\section{EXPLORING WHICH CHARACTERISTICS MATTER FOR TAX BUOYANCY}

The final exercise is to consider different determinants of tax buoyancy and check whether these make a difference when estimating short and long-run buoyancies. We consider four groups of potential characteristics that are known to affect the tax structure:

- $\quad$ Structural (namely the share of agriculture or mining in GDP and the degree of trade openness). In the early stages of development, the primary sector is characterized by "peasant agriculture", in which a large number of small producers sell their output in informal markets, sometimes in exchange for other goods, or produce for selfconsumption. The poor(er) or non-existing bookkeeping makes the agriculture sector a difficult sector to tax. Tanzi and Zee (2000) suggest that a large share of agriculture is associated with a small PIT and TGS. Same conclusions were reached by Ahmad and Stern (1991), Teera (2002), Stotsky and Wolde-Mariam (1997) and Ahsan and $\mathrm{Wu}$ (2005). Contrarily a high share of mining in GDP is positively correlated with the 
tax-to-GDP ratio (Celliah and others 1975; Tait et al 1979; Leuhold 1991; Bahl 2003; Alm and others 2004). Unlike the agriculture sector, the tradeable sector has been traditionally one that is easier to tax. This reflects the fact that administrative costs of monitoring, assessing, and collecting taxes on goods that go through a limited number of ports of entry are relatively low. Hence, the larger the relative size of the foreign trade sector, the larger tax collection in general (Lotz and Morss 1967; Tanzi 1987; Agbeyegbe et al 2004; Leuthold 1991; Mahdavi 2008).

- Demographic (namely population density and the level of education). Revenues from certain types are likely to grow with the extent of urbanization and the density of population. Efficiencies associated with monitoring and compliance in densely populated urban areas tend to boost revenue. Property taxes are also expected to increase as the value of land and real estate rise faster in more urban and densely populated areas (Ahsan and Wu 2005; Bahl 2003; Khattry and Mohan-Rao 2002; Mahdavi 2008). The relationship between tax rates and tax revenue generated from a given size of tax base is affected by factors that determine the administrative and enforcement costs of the tax system. One would expect that generating tax revenue from existing bases becomes more cost efficient as the level of education rises. A higher level of education enables the general public to better understand and comply with tax codes (Mahdavi 2008).

- Macroeconomic conditions (namely inflation and output volatility). High inflation rates when combined with payment and collection lags adversely affect tax revenues through several channels. For example, excise taxes on some products may be adversely affected if they do not fully adjust in a timely manner to changes in the inflation rate (Tanzi, 1989). Taxes on income, profits and capital gains may shrink in size to the extent that households try to protect their wealth against the corrosive effect of inflation by substituting towards assets that are less likely to be domestically taxes and/or postponing investment plans (Agbeyegbe et al 2004; Ghura, 1998). Output volatility, through shortening planning horizon and reducing the volume of economic activity, may adversely affect the level of taxation. The tax revenue mix may also change, and higher volatility is expected to be associated with less reliance on cyclically sensitive tax sources.

- Institutions (namely political rights and civil liberties). Recent studies have found that not only do supply factors matter, but also demand factors such as the quality of institutions have a significant impact on the determination of tax effort (Bird et al 2008). A legitimate and responsive state-one that secures the rule of law and keeps corruption under control-appears to be an essential pre condition for a more adequate tax collection effort (Fauvelle-Aymar 1999; Ehrhard 2009).

For each country in our sample we take the country-specific average of each of the above variables and then the cross-country average. We then split the sample between those countries 
above or below the resulting average value. Finally, we take the estimated short-run buoyancy coefficients presented in Tables A1.a-c and use them as our dependent variable in a crosscountry regression where the right-hand-side regressors are simply the previous set of determinants. We end up with a cross-section sample with a maximum of 107 observations. We estimate by Weighted Least Squares the following regression: ${ }^{10}$

$$
\widehat{\beta}_{i}=\alpha_{i}+\phi_{1} \text { Struc }_{i}+\phi_{2} \text { Demo }_{i}+\phi_{3} \text { Macro }_{i}+\phi_{4} \text { Inst }_{i}+\varepsilon_{i}, i=1,2, \ldots, 107
$$

where $\widehat{\beta}_{i}$ is an estimate of the tax buoyancy for country $i, \alpha_{i}$ is a constant term, and $\phi_{1}-\phi_{4}$ are slope parameters to be estimated. The disturbance term, $\varepsilon_{i}$, is assumed to have zero mean and constant variance.

Our results are displayed in Table 9. We can see that, in adherence with the hypothesis outlined above, trade openness and human capital increase revenue buoyancy while inflation and output volatility decrease it. ${ }^{11}$

Table 9. Determinants of Tax Buoyancy: Total Taxes

\begin{tabular}{|c|c|c|c|c|c|c|c|}
\hline Specification & (1) & (2) & (3) & (4) & (5) & (6) & (7) \\
\hline Share of Agriculture & $\begin{array}{l}-0.049 \\
(0.048)\end{array}$ & & & & $\begin{array}{l}-0.016 \\
(0.055)\end{array}$ & $\begin{array}{l}-0.001 \\
(0.042)\end{array}$ & $\begin{array}{l}-0.015 \\
(0.046)\end{array}$ \\
\hline Trade openness & $\begin{array}{c}0.113 \\
(0.095)\end{array}$ & & & & $\begin{array}{c}0.349 * * * \\
(0.087)\end{array}$ & $\begin{array}{c}0.424 * * * \\
(0.089)\end{array}$ & $\begin{array}{c}0.447 * * * \\
(0.078)\end{array}$ \\
\hline Population density & & $\begin{array}{l}0.004 * \\
(0.002)\end{array}$ & & & $\begin{array}{c}0.027 * * * \\
(0.007)\end{array}$ & $\begin{array}{c}0.033 * * * \\
(0.007)\end{array}$ & $\begin{array}{c}0.037 \\
(0.027)\end{array}$ \\
\hline Human capital & & $\begin{array}{c}-0.004 \\
(0.080)\end{array}$ & & & $\begin{array}{c}0.097 \\
(0.073)\end{array}$ & $\begin{array}{c}0.190 * * * \\
(0.064)\end{array}$ & $\begin{array}{c}0.060 \\
(0.110)\end{array}$ \\
\hline Inflation & & & $\begin{array}{l}-0.048 \\
(0.041)\end{array}$ & & & $\begin{array}{c}-0.102^{*} \\
(0.059)\end{array}$ & $\begin{array}{l}-0.104 \\
(0.065)\end{array}$ \\
\hline Output volatility & & & $\begin{array}{l}-0.022 \\
(0.022)\end{array}$ & & & $\begin{array}{c}-0.055^{* * *} \\
(0.018)\end{array}$ & $\begin{array}{c}-0.064 * * * \\
(0.018)\end{array}$ \\
\hline Civil liberties & & & & $\begin{array}{c}0.050 \\
(0.067)\end{array}$ & & & $\begin{array}{c}0.079 \\
(0.108)\end{array}$ \\
\hline Political rights & & & & $\begin{array}{c}0.100 \\
(0.073)\end{array}$ & & & $\begin{array}{c}0.007 \\
(0.109)\end{array}$ \\
\hline Observations & 93 & 86 & 100 & 71 & 81 & 80 & 62 \\
\hline$R$-squared & 0.027 & 0.002 & 0.119 & 0.078 & 0.120 & 0.339 & 0.406 \\
\hline
\end{tabular}

\footnotetext{
10 The weights are given by the inverse of the standard errors of the estimated tax buoyancies.

11 The reduced-form representation displayed in equation (5) should not be viewed as a universal model of buoyancy. For example, the estimated effect of trade openness may not be same all country groups. While such a result might plausible apply to a group of emerging and low income countries with weak tax systems, this is not the case for other sub-groups. For instance, the trade-creation effect of EMU is not expected to have increased tax buoyancy in the euro area.
} 
Table 10. Determinants of Tax Buoyancy: Alternative Tax Categories

\begin{tabular}{|c|c|c|c|c|c|c|c|}
\hline Specification & (1) & (2) & (3) & (4) & (5) & (6) & (7) \\
\hline $\begin{array}{l}\text { Dependent } \\
\text { Variable } \\
\end{array}$ & $\begin{array}{c}\text { PIT } \\
\text { buoyancy }\end{array}$ & $\begin{array}{c}\text { PIT } \\
\text { buoyancy }\end{array}$ & $\begin{array}{c}\text { PIT } \\
\text { buoyancy }\end{array}$ & $\begin{array}{c}\text { CIT } \\
\text { buoyancy }\end{array}$ & $\begin{array}{c}\text { CIT } \\
\text { buoyancy }\end{array}$ & $\begin{array}{c}\text { TGS } \\
\text { buoyancy }\end{array}$ & $\begin{array}{c}\text { TGS } \\
\text { buoyancy }\end{array}$ \\
\hline $\begin{array}{l}\text { Share of } \\
\text { Agriculture }\end{array}$ & & & & & 0.386 & $-0.118^{*}$ & -0.062 \\
\hline & & & & & $(0.402)$ & $(0.070)$ & $(0.064)$ \\
\hline Trade openness & & & & & $\begin{array}{l}0.818^{*} \\
(0.450)\end{array}$ & $\begin{array}{c}0.013 \\
(0.134)\end{array}$ & $\begin{array}{c}0.202 \\
(0.122)\end{array}$ \\
\hline $\begin{array}{l}\text { Population } \\
\text { density }\end{array}$ & & & 0.071 & & -0.097 & & $0.033 * * *$ \\
\hline & & & $(0.234)$ & & $(0.241)$ & & $(0.010)$ \\
\hline Human capital & & & $\begin{array}{c}1.044 * * * \\
(0.339)\end{array}$ & & $\begin{array}{c}1.272 * * * \\
(0.355)\end{array}$ & & $\begin{array}{l}0.162 * \\
(0.084)\end{array}$ \\
\hline Inflation & $\begin{array}{c}0.180 \\
(0.122)\end{array}$ & & & & $\begin{array}{l}-0.203^{*} \\
(0.119)\end{array}$ & & $\begin{array}{c}0.105 \\
(0.094)\end{array}$ \\
\hline Output volatility & $\begin{array}{c}-0.045^{* * *} \\
(0.017)\end{array}$ & & & & $\begin{array}{c}-0.192^{* *} \\
(0.093)\end{array}$ & & $\begin{array}{c}-0.076^{* * * *} \\
(0.021)\end{array}$ \\
\hline Civil liberties & & $\begin{array}{c}0.313^{* *} \\
(0.121)\end{array}$ & & $\begin{array}{l}0.904 * \\
(0.477)\end{array}$ & & & \\
\hline Political rights & & $\begin{array}{l}0.243^{*} \\
(0.124)\end{array}$ & & $\begin{array}{c}0.377 \\
(0.399)\end{array}$ & & & \\
\hline Observations & 66 & 54 & 63 & 54 & 59 & 79 & 71 \\
\hline$R$-squared & 0.129 & 0.086 & 0.209 & 0.312 & 0.335 & 0.040 & 0.334 \\
\hline
\end{tabular}

We repeat the exercise replacing overall tax buoyancy estimates as the dependent variable by the PIT, CIT and TGS buoyancy estimates (Table 10). ${ }^{12}$ Yet again, higher output volatility reduces the ability to collect revenues, particularly CIT since investment decisions rely heavily of expectations about the future. Inflation also has a more damaging impact when it comes to CIT buoyancy since it quickly erodes profit margins. Moreover, interestingly, now the coefficient on the share of agriculture is now negative and statistically significant in specification 6 for TGS, in line with the literature discussed earlier. Finally, a better institutional environment acts as a disciplinary mechanism for tax compliance for both individuals and corporations (see specifications 2 and 4).

\section{ConClusion ANd Policy IMPlications}

This empirical paper aims at first estimating short- and long-run tax buoyancies estimates for 107 countries between 1980 and 2014 and then analyzing their determinants. We also inspect the behavior of tax buoyancies around business cycles' turning points, in particular the recent Global Financial Crisis. We do so by relying on both time series and panel data techniques (such as Fully-Modified OLS or (Pooled) Mean Group estimators).

We find that, on average, long-run buoyancy of total revenue is not different from one in all country groups. Short-run buoyancy is not statistically different from one in advanced

\footnotetext{
${ }^{12}$ Due to insufficient number of individual country estimates for the SSC, WLS regressions were not performed.
} 
economies, while it is generally statistically larger than one in emerging markets and low income countries. By going more granular into specific tax categories, our results suggest that long run tax buoyancy exceeds one in the case of CIT for advanced economies, PIT and SSC in emerging markets, and TGS for low income countries. In addition, tax buoyancy does not appear neutral with respect to inflation, meaning that tax buoyancy in real terms is smaller than in nominal.

When it comes to turning points, in advanced countries only CIT buoyancy is larger during contractions than during times of economic expansions, suggesting that this tax category works better as output stabilizer during bad times. In emerging market economies, this effect is attributed to CIT but also to TGS, whose buoyancy coefficients were found to be statistically larger than one during periods of relatively low growth.

Finally, as far as the main determinants of tax buoyancy are concerned, both trade openness and human capital increase it while inflation and output volatility decrease it.

Because tax revenue tends to remain constant, as a share of GDP, over the long run, an implication of our findings is that permanent increases in the ratio of spending-to-GDP that do not affect improve structural condition or human capital should be accompanied by reform aimed at mobilizing revenues, in order to avoid a permanent deterioration in the fiscal balance. Also, reliance on the CIT improves the stabilization role of the revenue system especially during a recession, but the decline in the CIT collection as a share of GDP could be large and might take a longer expansion to recover. 


\section{Appendix Tables}

Table A1a. Overall Tax Buoyancy by country, Advanced Economies

\begin{tabular}{|c|c|c|c|}
\hline & Long run buoyancy & Short run buoyancy & Speed of Adjustment \\
\hline Australia & $0.953 * * *$ & $1.004^{* * *}$ & -0.153 \\
\hline Austria & $1.000 * * *$ & $0.565 * *$ & $-0.382 * * *$ \\
\hline Belgium & $1.013 * * *$ & $0.965 * * *$ & $-0.209^{*}$ \\
\hline Canada & $0.550 * *$ & $1.179 * * *$ & $-0.095 * * *$ \\
\hline Cyprus & $1.446^{* * *}$ & $2.415 * * *$ & $-0.635 * * *$ \\
\hline Czech Republic & $1.016 * * *$ & $1.230 * * *$ & $-0.660 * *$ \\
\hline Denmark & $1.017 * * *$ & $0.898 * * *$ & $-0.219^{* *}$ \\
\hline Estonia & $1.019 * * *$ & $0.841 * * *$ & $-0.931 * * *$ \\
\hline Finland & $1.007 * * *$ & $0.947 * * *$ & $-0.180 * *$ \\
\hline France & $1.054 * * *$ & $1.317 * * *$ & $-0.093 * *$ \\
\hline Germany & $1.422 * * *$ & $1.921^{* * *}$ & $-0.136 * *$ \\
\hline Greece & $1.953 * * *$ & $1.048 * * *$ & $-0.332 * *$ \\
\hline Iceland & $0.929 * * *$ & $0.828 * * *$ & -0.125 \\
\hline Ireland & $0.911 * * *$ & $1.045 * * *$ & $-0.365 * * *$ \\
\hline Israel & $0.696 * * *$ & $1.471 * *$ & $-0.614 * *$ \\
\hline Italy & $0.807 * * *$ & $0.593 * *$ & $-0.170 * * *$ \\
\hline Japan & $0.864 * * *$ & $1.054 * * *$ & -0.154 \\
\hline Korea & $1.098 * * *$ & $1.347 * * *$ & $-0.792 * * *$ \\
\hline Luxembourg & 0.459 & $0.809 * * *$ & -0.053 \\
\hline Netherlands & -0.757 & $0.957 * * *$ & -0.021 \\
\hline New Zealand & 7.792 & $2.016^{* * *}$ & 0.006 \\
\hline Norway & 3.872 & $1.590 * * *$ & 0.021 \\
\hline Portugal & $1.295 * * *$ & $1.993 * * *$ & $-0.308 * * *$ \\
\hline Singapore & $0.840 * * *$ & $1.164 * * *$ & -0.209 \\
\hline Slovak Republic & $0.798 * * *$ & $1.095 * * *$ & $-0.547 * *$ \\
\hline Slovenia & $1.017 * * *$ & $1.290 * * *$ & $-0.854 * * *$ \\
\hline Spain & 0.491 & $1.396 * * *$ & -0.056 \\
\hline Sweden & $0.947 * * *$ & $1.177 * * *$ & $-0.181 *$ \\
\hline Switzerland & $1.090 * * *$ & $0.752 * *$ & $-0.531 * * *$ \\
\hline United Kingdom & $1.006 * * *$ & $1.234 * * *$ & $-0.226^{* *}$ \\
\hline United States & 1.407 & $2.652^{* * *}$ & -0.024 \\
\hline Mean & 1.262 & 1.203 & \\
\hline Median & 1.007 & 1.095 & \\
\hline Standard Deviation & 1.437 & 0.438 & \\
\hline
\end{tabular}

Note: Bold italic means statistically greater than one at 5 percent level; bold means statistically not different from one at 5 percent level. *, **,*** denote statistical significance at the 10,5 and 1 percent levels, respectively. 


\section{Table A1b. Overall Tax Buoyancy by Country, Emerging Market Economies}

\begin{tabular}{|c|c|c|c|}
\hline & Long run buoyancy & Short run buoyancy & Speed of Adjustment \\
\hline Algeria & $1.211 * * *$ & $1.849 * * *$ & $-0.494 * * *$ \\
\hline Angola & $1.140 * * *$ & $1.471 * * *$ & $-0.750 * *$ \\
\hline Argentina & $1.144 * * *$ & $1.407 * * *$ & $-0.546^{* *}$ \\
\hline Azerbaijan & $0.981 * * *$ & $1.459 * * *$ & $-0354 * *$ \\
\hline Belarus & 0.751 & $1.131 * *$ & -0.08 \\
\hline Brazil & $0.976 * * *$ & $1.306 * * *$ & -0.206 \\
\hline Chile & $1.157 * * *$ & $1.939 * * *$ & $-0.579 * * *$ \\
\hline China & $1.238 * * *$ & $0.656^{* * *}$ & -0.065 \\
\hline Colombia & $1.249 * * *$ & $1.558 * * *$ & $-0.720 * * *$ \\
\hline Croatia & $1.033 * * *$ & $1.302 * * *$ & $-0.791 * *$ \\
\hline Dominican Republic & $1.068 * * *$ & $0.887 * * *$ & $-0.473 * *$ \\
\hline Ecuador & $1.383 * * *$ & $0.861 * * *$ & $-0.689 * * *$ \\
\hline Egypt & $0.974 * * *$ & $1.628 * * *$ & $-0.650 * *$ \\
\hline Hungary & $0.922 * * *$ & 0.431 & $-0.780 * * *$ \\
\hline India & $1.104 * * *$ & $1.668 * * *$ & $-0.669 * * *$ \\
\hline Indonesia & $1.109 * * *$ & $0.998 * * *$ & $-0.491 * *$ \\
\hline Iran & $1.028 * * *$ & 0.33 & $-0.509 * * *$ \\
\hline Kazakhstan & $1.111^{* * *}$ & $2.023^{* * *}$ & $-0.663 * * *$ \\
\hline Kuwait & $0.958 * * *$ & $1.997 * * *$ & $-0.469 * *$ \\
\hline Libya & 0.072 & $0.933 * * *$ & -0.214 \\
\hline Mexico & $1.001 * * *$ & $0.624 *$ & $-0.481 * *$ \\
\hline Morocco & $1.197 * * *$ & $0.604 *$ & $-0.484 * *$ \\
\hline Oman & $1.272 * * *$ & 0.241 & $-0.479 * * *$ \\
\hline Pakistan & $0.981 * * *$ & $0.909 * * *$ & $-0.815 * * *$ \\
\hline Peru & $1.142 * *$ & $2.049 * * *$ & $-0.430 * *$ \\
\hline Philippines & $1.064 * * *$ & $2.267 * * *$ & -0.224 \\
\hline Poland & $1.071 * * *$ & $2.205^{* * *}$ & -0.661 \\
\hline Qatar & $1.666^{* * *}$ & 0.389 & $-0.983 * * *$ \\
\hline Romania & $1.068 * * *$ & $1.185^{* * *}$ & -0.678 \\
\hline Russia & $1.109 * * *$ & $1.326 * * *$ & -0.394 \\
\hline Saudi Arabia & $0.799 * * *$ & $0.919 * * *$ & $-0.838 * * *$ \\
\hline South Africa & $1.072 * * *$ & $1.610 * * *$ & $-0.434 *$ \\
\hline Thailand & $1.208 * * *$ & $1.780 * * *$ & $-0.371 * *$ \\
\hline Turkey & $1.176^{* * *}$ & $1.554 * * *$ & $-0.931^{* * *}$ \\
\hline Ukraine & $1.120 * * *$ & $1.114 * * *$ & $0.536^{* * *}$ \\
\hline United Arab Emirates & $1.347 * * *$ & $2.888 * * *$ & -0.186 \\
\hline Uruguay & $1.007 * * *$ & $1.231 * * *$ & -0.329 \\
\hline Venezuela & $1.039 * * *$ & $0.897 * * *$ & $-0.582 * *$ \\
\hline Mean & 1.06 & 1.31 & \\
\hline Median & 1.07 & 1.23 & \\
\hline Standard Deviation & 0.25 & 0.65 & \\
\hline
\end{tabular}

Note: Bold italic means statistically greater than one at 5 percent level; bold means statistically not different from one at 5 percent level. $* * *, * * *$ denote statistical significance at the 10,5 and 1 percent levels, respectively. 
Table A1c. Overall Tax Buoyancy by Country, Low Income Countries

\begin{tabular}{|c|c|c|c|c|c|}
\hline & Long run buoyancy & \multicolumn{2}{|c|}{ Short run buoyancy } & \multicolumn{2}{|c|}{ Speed of Adjustment } \\
\hline Bolivia & $1.281 * * *$ & $1.732^{* * *}$ & & & -0.337 \\
\hline Bangladesh & $1.198 * * *$ & & 0.777 & $-0.544 * * *$ & \\
\hline Benin & $1.206 * * *$ & $0.932 * * *$ & & $-0.345^{* *}$ & \\
\hline Burkina Faso & $1.435 * * *$ & & 0.301 & $-0.572 * *$ & \\
\hline Cameroon & $1.001 * * *$ & $3.814 * *$ & & $-0.749 * * *$ & \\
\hline Chad & $1.638 * * *$ & & 0.021 & $-0.670 * * *$ & \\
\hline Congo, Dem Rep & $1.360 * * *$ & $0.524 * * *$ & & $-0.760 * * *$ & \\
\hline Congo, Rep & $1.089 * * *$ & $0.372 *$ & & $-0.321^{*}$ & \\
\hline Cote Ivoire & $1.036 * * *$ & $1.874 * * *$ & & $-0.931 * * *$ & \\
\hline Ethiopia & $1.320 * * *$ & $0.455^{*}$ & & $-0.284 * *$ & \\
\hline Ghana & $1.156 * * *$ & & 0.913 & $-0.521 * *$ & \\
\hline Guinea & $1.233 * * *$ & $1.350 * * *$ & & $-0.446 * * *$ & \\
\hline Haiti & $1.301 * * *$ & $0.974 * * *$ & & $-0.405 * *$ & \\
\hline Honduras & $1.031 * * *$ & $0.977 * * *$ & & $-0.815 * * *$ & \\
\hline Kenya & $1.133 * * *$ & $1.078 *$ & & $-0.361 * *$ & \\
\hline Kyrgyz & $1.181 * * *$ & & 0.442 & & -0.162 \\
\hline Lao & $1.349 * * *$ & & 0.489 & $-0.311 * *$ & \\
\hline Madagascar & $1.039 * * *$ & $2.252 * * *$ & & $-0.681 * * *$ & \\
\hline Mali & $0.925 * * *$ & & 0.325 & $-0.403 * *$ & \\
\hline Moldova & $1.022 * * *$ & $0.779 * *$ & & $-0.467 * *$ & \\
\hline Mozambique & $1.089 * * *$ & $0.878 * * *$ & & & -0.18 \\
\hline Myanmar & $1.358 * * *$ & & 0.212 & & -0.26 \\
\hline Nepal & $1.409 * * *$ & $1.515 * * *$ & & $-0.742 * *$ & \\
\hline Nicaragua & $1.223 * * *$ & $1.421 * * *$ & & $-0.742 *$ & \\
\hline Niger & $1.528 * * *$ & $0.889 * * *$ & & $-0.751 * * *$ & \\
\hline Nigeria & $0.864 * * *$ & & 0.228 & $-0.900 * * *$ & \\
\hline Papua New Guinea & $1.121 * * *$ & $1.093 * *$ & & $-0.520 * *$ & \\
\hline Rwanda & $1.275 * * *$ & $2.200 * * *$ & & & -0.074 \\
\hline Senegal & $1.193 * * *$ & $1.987 * * *$ & & $-0.942 * *$ & \\
\hline Sudan & $0.598 * *$ & $0.350 * *$ & & & -0.209 \\
\hline Tajikistan & $1.134 * * *$ & $1.279 * * *$ & & $-0.931 * * *$ & \\
\hline Tanzania & $1.194 * * *$ & $2.312 * * *$ & & $-0.683 * * *$ & \\
\hline Uganda & $1.184 * * *$ & & 0.258 & & -0.285 \\
\hline Uzbekistan & $0.904 * * *$ & $0.697 * * *$ & & $-0.894 * * *$ & \\
\hline Vietnam & $0.906 * * *$ & $1.309 * * *$ & & & -0.247 \\
\hline Yemen & $0.957 * * *$ & $0.809 * * *$ & & $-0.703 * * *$ & \\
\hline Zambia & 1.756 & $2.565 * *$ & & & -0.135 \\
\hline Zimbabwe & $3.011 *$ & $5.451 * * *$ & & & -0.567 \\
\hline Mean & 1.23 & 1.27 & & & \\
\hline Median & 1.16 & 0.91 & & & \\
\hline Standard Deviation & 0.42 & 1.19 & & & \\
\hline
\end{tabular}

Note: Bold italic means statistically greater than one at 5 percent level; bold means statistically not different from one at 5 percent level. $*, * *, * * *$ denote statistical significance at the 10,5 and 1 percent levels, respectively. 
Table A2. First Generation Panel Unit Root Tests

Im, Pesaran and Shin (2003) Panel Unit Root Test (IPS) (a)

\begin{tabular}{|c|c|c|c|c|c|c|c|c|c|c|c|c|}
\hline & & GDP & & Tax revenue & & PIT & & CIT & & TGS & & SSC \\
\hline \multicolumn{13}{|l|}{$\begin{array}{c}\text { in } \\
\text { levels }\end{array}$} \\
\hline & $\operatorname{lags}$ & {$[t-b a r]$} & $\operatorname{lags}$ & {$[t-b a r]$} & lags & {$[t-b a r]$} & $\operatorname{lags}$ & [t-bar] & $\operatorname{lags}$ & {$[t-b a r]$} & lags & $\begin{array}{c}{[t-} \\
\text { bar] }\end{array}$ \\
\hline $\mathrm{AE}$ & 0.90 & 2.36 & 1.13 & 1.09 & 0.76 & $-1.33^{*}$ & 0.90 & -0.69 & 1.13 & 0.65 & 0.78 & -0.95 \\
\hline EME & 1.45 & $\begin{array}{c}- \\
9.52^{* * *}\end{array}$ & 1.34 & $-2.80 * * *$ & 1.45 & $\begin{array}{c}- \\
2.53^{* * *}\end{array}$ & 0.80 & -0.76 & & & 1.40 & \\
\hline LIC & 0.82 & $9.61^{-} * * *$ & 0.95 & $-4.61 * * *$ & 1.47 & $-1.31^{*}$ & 0.94 & $2.17^{* *}$ & 0.91 & $1.85 * *$ & 1.71 & \\
\hline
\end{tabular}

Maddala and Wu (1999) Panel Unit Root Test (MW) (b)

\begin{tabular}{|c|c|c|c|c|c|c|c|c|c|c|c|c|c|}
\hline & & GDP & & $\begin{array}{c}\text { Tax } \\
\text { revenue }\end{array}$ & & PIT & & CIT & & TGS & & SSC & \\
\hline & lags & $p_{\lambda}$ & (p) & $p_{\lambda}$ & (p) & $p_{\lambda}$ & (p) & $p_{\lambda}$ & (p) & $p_{\lambda}$ & (p) & $p_{\lambda}$ & (p) \\
\hline $\mathrm{AE}$ & $\begin{array}{c}\text { in } \\
\text { levels } \\
0 \\
1 \\
2 \\
\end{array}$ & $\begin{array}{c}97.06 \\
42.740 \\
46.97\end{array}$ & $\begin{array}{l}(0.00) \\
(0.81) \\
(0.67) \\
\end{array}$ & $\begin{array}{c}154.67 \\
56.95 \\
53.21\end{array}$ & $\begin{array}{c}(0.00) \\
(0.296) \\
(0.42) \\
\end{array}$ & $\begin{array}{c}113.46 \\
98.41 \\
60.95\end{array}$ & $\begin{array}{l}(0.00) \\
(0.00) \\
(0.18) \\
\end{array}$ & $\begin{array}{l}52.14 \\
68.69 \\
60.01 \\
\end{array}$ & $\begin{array}{l}(0.46) \\
(0.06) \\
(0.21) \\
\end{array}$ & $\begin{array}{c}124.54 \\
51.71 \\
50.20 \\
\end{array}$ & $\begin{array}{l}(0.00) \\
(0.48) \\
(0.15) \\
\end{array}$ & $\begin{array}{c}132.27 \\
73.99 \\
59.57 \\
\end{array}$ & $\begin{array}{l}(0.00) \\
(0.02) \\
(0.22) \\
\end{array}$ \\
\hline EME & $\begin{array}{c}\text { in } \\
\text { levels } \\
0 \\
1 \\
2 \\
\end{array}$ & $\begin{array}{c}101.74 \\
53.06 \\
50.45\end{array}$ & $\begin{array}{l}(0.00) \\
(0.01) \\
(0.02) \\
\end{array}$ & $\begin{array}{l}28.75 \\
41.82 \\
44.47 \\
\end{array}$ & $\begin{array}{l}(0.63) \\
(0.11) \\
(0.07) \\
\end{array}$ & $\begin{array}{l}26.15 \\
81.78 \\
31.59 \\
\end{array}$ & $\begin{array}{l}(0.75) \\
(0.00) \\
(0.48) \\
\end{array}$ & $\begin{array}{l}18.24 \\
46.83 \\
31.17 \\
\end{array}$ & $\begin{array}{l}(0.97) \\
(0.04) \\
(0.50) \\
\end{array}$ & $\begin{array}{l}65.85 \\
37.45 \\
36.61 \\
\end{array}$ & $\begin{array}{l}(0.00) \\
(0.23) \\
(0.26) \\
\end{array}$ & $\begin{array}{l}47.85 \\
77.35 \\
56.21 \\
\end{array}$ & $\begin{array}{l}(0.04) \\
(0.00) \\
(0.01) \\
\end{array}$ \\
\hline LIC & $\begin{array}{c}\text { in } \\
\text { levels } \\
0 \\
1 \\
2\end{array}$ & $\begin{array}{l}0.30 \\
0.20 \\
0.23\end{array}$ & $\begin{array}{l}(0.85) \\
(0.90) \\
(0.89)\end{array}$ & $\begin{array}{l}0.42 \\
0.28 \\
0.36\end{array}$ & $\begin{array}{l}(0.81) \\
(0.86) \\
(0.83)\end{array}$ & $\begin{array}{l}0.29 \\
1.04 \\
3.99\end{array}$ & $\begin{array}{l}(0.86) \\
(0.59) \\
(0.14)\end{array}$ & $\begin{array}{l}1.05 \\
4.60 \\
3.63\end{array}$ & $\begin{array}{l}(0.59) \\
(0.10) \\
(0.16)\end{array}$ & $\begin{array}{l}1.05 \\
0.46 \\
0.03\end{array}$ & $\begin{array}{l}(0.59) \\
(0.79) \\
(0.98)\end{array}$ & $\begin{array}{l}0.14 \\
1.20 \\
1.31 \\
\end{array}$ & $\begin{array}{l}(0.93) \\
(0.54) \\
(0.51)\end{array}$ \\
\hline
\end{tabular}

Notes: All variables are in logarithms. (a) We report the average of the country-specific "ideal" lag-augmentation (via AIC). We report the t-bar statistic, constructed as $t$-bar $=(1 / N) \sum_{i} t_{i}\left(t_{i}\right.$ are country ADF t-statistics). Under the null of all country series containing a nonstationary process this statistic has a non-standard distribution: the critical values $(-1.73$ for $5 \%,-1.69$ for $10 \%$ significance level - distribution is approximately $t$ ) are reported in Table 2, Panel A of their paper. We indicate the cases where the null is rejected with ***. (b) We report the MW statistic constructed as $p_{\lambda}=-2 \sum_{i} \log \left(p_{i}\right)\left(p_{i}\right.$ are country ADF statistic p-values) for different lag-augmentations. Under the null of all country series containing a nonstationary process this statistic is distributed $\chi^{2}(2 N)$. We further report the p-values for each of the MW tests.

Table A3. Second Generation Panel Unit Root Tests

Pesaran (2007) Panel Unit Root Test (CIPS)

\begin{tabular}{|c|c|c|c|c|c|c|c|c|c|c|c|c|c|}
\hline & & GDP & & Tax revenue & & PIT & & CIT & & TGS & & SSC & \\
\hline & lags & $p_{\lambda}$ & (p) & $p_{\lambda}$ & (p) & $p_{\lambda}$ & (p) & $p_{\lambda}$ & (p) & $p_{\lambda}$ & (p) & $p_{\lambda}$ & (p) \\
\hline $\mathrm{AE}$ & $\begin{array}{c}\text { in levels } \\
0 \\
1 \\
2 \\
\end{array}$ & $\begin{array}{c}3.627 \\
2.453 \\
3.31 \\
\end{array}$ & $\begin{array}{l}(1.00) \\
(0.99) \\
(1.00)\end{array}$ & $\begin{array}{l}1.58 \\
0.47 \\
1.42\end{array}$ & $\begin{array}{l}(0.94) \\
(0.68) \\
(0.92)\end{array}$ & $\begin{array}{c}1.52 \\
-0.45 \\
0.72 \\
\end{array}$ & $\begin{array}{l}(0.93) \\
(0.32) \\
(0.77)\end{array}$ & $\begin{array}{c}-1.11 \\
0.48 \\
0.96 \\
\end{array}$ & $\begin{array}{l}(0.13) \\
(0.68) \\
(0.83)\end{array}$ & $\begin{array}{l}1.16 \\
0.92 \\
1.25\end{array}$ & $\begin{array}{l}(0.87) \\
(0.82) \\
(0.89)\end{array}$ & $\begin{array}{l}1.62 \\
1.63 \\
1.28 \\
\end{array}$ & $\begin{array}{l}(0.94) \\
(0.94) \\
(0.90)\end{array}$ \\
\hline EME & $\begin{array}{c}\text { in levels } \\
0 \\
1 \\
2 \\
\end{array}$ & $\begin{array}{c}0.78 \\
-2.82 \\
4.12 \\
\end{array}$ & $\begin{array}{l}(0.78) \\
(0.00) \\
(1.00) \\
\end{array}$ & $\begin{array}{c}-0.23 \\
0.10 \\
4.05 \\
\end{array}$ & $\begin{array}{l}(0.40) \\
(0.54) \\
(1.00)\end{array}$ & $\begin{array}{l}0.38 \\
1.55 \\
3.37 \\
\end{array}$ & $\begin{array}{l}(0.65) \\
(0.94) \\
(1.00)\end{array}$ & $\begin{array}{c}-0.03 \\
-1.89 \\
4.94 \\
\end{array}$ & $\begin{array}{r}(0.48) \\
(0.03) \\
(1.00) \\
\end{array}$ & $\begin{array}{l}0.20 \\
1.08 \\
4.19 \\
\end{array}$ & $\begin{array}{l}(0.57) \\
(0.86) \\
(1.00)\end{array}$ & $\begin{array}{l}2.64 \\
0.53 \\
4.26 \\
\end{array}$ & $\begin{array}{l}(0.99) \\
(0.70) \\
(1.00) \\
\end{array}$ \\
\hline LIC & $\begin{array}{c}\text { in levels } \\
0 \\
1 \\
2 \\
\end{array}$ & $\begin{array}{l}3.17 \\
1.05 \\
0.93\end{array}$ & $\begin{array}{l}(0.20) \\
(0.58) \\
(0.62)\end{array}$ & $\begin{array}{l}0.32 \\
0.50 \\
0.18\end{array}$ & $\begin{array}{l}(0.85) \\
(0.77) \\
(0.91)\end{array}$ & $\begin{array}{l}0.16 \\
0.29 \\
0.14\end{array}$ & $\begin{array}{l}(0.92) \\
(0.86) \\
(0.93)\end{array}$ & $\begin{array}{l}0.25 \\
0.85 \\
0.70\end{array}$ & $\begin{array}{c}(0.88) \\
(0.65) \\
(0.70)\end{array}$ & $\begin{array}{l}0.76 \\
1.84 \\
0.53\end{array}$ & $\begin{array}{c}(0.68) \\
(0.39) \\
(0.76)\end{array}$ & $\begin{array}{l}0.20 \\
0.19 \\
1.52\end{array}$ & $\begin{array}{l}(0.90) \\
(0.91) \\
(0.46)\end{array}$ \\
\hline
\end{tabular}

Notes: All variables are in logarithms. The null hypothesis is of nonstationarity. 
Table A4. Overall Tax Buoyancy during the Global Financial Crisis

\begin{tabular}{r|cc|cc|cc}
\hline \multicolumn{2}{c|}{ Country group } & \multicolumn{2}{c|}{$A E$} & \multicolumn{2}{c|}{ EME } & \multicolumn{2}{c}{ LIC } \\
\hline & MG & PMG & MG & PMG & MG & PMG \\
\hline Long run buoyancy & -0.129 & $\mathbf{1 . 1 0 2 * * *}$ & $\mathbf{1 . 1 9 3 * * *}$ & $\mathbf{1 . 7 0 5 * * *}$ & -1.870 & $0.596^{* * *}$ \\
& $(0.801)$ & $(0.002)$ & $(0.171)$ & $(0.065)$ & $(2.855)$ & $(0.003)$ \\
Short run buoyancy & $\mathbf{1 . 2 4 9} * * *$ & $\mathbf{1 . 1 9 0 * * *}$ & $\mathbf{2 . 1 7 1 * * *}$ & $\mathbf{1 . 7 3 4 * * *}$ & $\mathbf{1 . 7 0 9 * * *}$ & $\mathbf{1 . 5 7 3 * * *}$ \\
& $(0.124)$ & $(0.113)$ & $(0.291)$ & $(0.207)$ & $(0.612)$ & $(0.295)$ \\
Speed of adjustment & $-0.887 * * *$ & $-0.765 * * *$ & -0.266 & $-0.253 * * *$ & $-0.369 * *$ & -0.126 \\
& $(0.179)$ & $(0.172)$ & $(0.302)$ & $(0.080)$ & $(0.186)$ & $(0.101)$ \\
Observations & 155 & 155 & 190 & 190 & 190 & 190 \\
\# Countries & 31 & 31 & 38 & 38 & 38 & 38 \\
\hline
\end{tabular}

Note: Estimation of Equation (3) by PMG estimator (see main text for details). Bold italic means statistically greater than one at 5 percent level; bold means statistically not different from one at 5 percent level. Standard errors in parenthesis. *,**,*** denote statistical significance at the 10,5 and 1 percent levels, respectively.

Table A5. Buoyancy of Tax Revenue Components during the Global Financial Crisis

\begin{tabular}{|c|c|c|c|c|}
\hline$A E$ & PIT & CIT & $T G S$ & $S S C$ \\
\hline Long run buoyancy & $\begin{array}{c}1.698 * * * \\
(0.027)\end{array}$ & $\begin{array}{c}\mathbf{0 . 7 9 9} * * * \\
(0.104)\end{array}$ & $\begin{array}{l}1.625 * * * \\
(0.011)\end{array}$ & $\begin{array}{c}0.820^{* * *} \\
(0.026)\end{array}$ \\
\hline Short run buoyancy & $\begin{array}{c}1.033 * * * \\
(0.202)\end{array}$ & $\begin{array}{c}3.541^{* * * *} \\
(0.614)\end{array}$ & $\begin{array}{c}1.219 * * * \\
(0.186)\end{array}$ & $\begin{array}{c}\mathbf{0 . 6 2 6 * * *} \\
(0.192)\end{array}$ \\
\hline Speed of adjustment & $\begin{array}{c}-0.553^{* * * *} \\
(0.115)\end{array}$ & $\begin{array}{c}-0.454 * * * \\
(0.171)\end{array}$ & $\begin{array}{c}-0.423 * * * \\
(0.084)\end{array}$ & $\begin{array}{c}-0.439 * * * \\
(0.166)\end{array}$ \\
\hline $\begin{array}{r}\text { Observations } \\
\text { \# Countries }\end{array}$ & $\begin{array}{c}145 \\
29\end{array}$ & $\begin{array}{c}145 \\
29\end{array}$ & $\begin{array}{c}150 \\
30\end{array}$ & $\begin{array}{c}140 \\
27\end{array}$ \\
\hline$E M E$ & PIT & CIT & TGS & SSC \\
\hline Long run buoyancy & $\begin{array}{c}1.077 * * * \\
(0.009)\end{array}$ & $\begin{array}{c}0.889 * * * \\
(0.000)\end{array}$ & $\begin{array}{l}1.196 * * * \\
(0.006)\end{array}$ & $\begin{array}{l}- \\
-\end{array}$ \\
\hline Short run buoyancy & $\begin{array}{c}1.364 * * * \\
(0.282)\end{array}$ & $\begin{array}{c}\mathbf{1 . 5 4 1} * * * \\
(0.305)\end{array}$ & $\begin{array}{c}1.347 * * * \\
(0.183)\end{array}$ & $\begin{array}{l}- \\
-\end{array}$ \\
\hline Speed of adjustment & $\begin{array}{c}-0.722 * * * \\
(0.104)\end{array}$ & $\begin{array}{c}-0.717 * * * \\
(0.092)\end{array}$ & $\begin{array}{c}-0.779 * * * \\
(0.157)\end{array}$ & $\begin{array}{l}- \\
-\end{array}$ \\
\hline $\begin{array}{r}\text { Observations } \\
\text { \# Countries } \\
\end{array}$ & $\begin{array}{c}110 \\
22 \\
\end{array}$ & $\begin{array}{l}125 \\
25 \\
\end{array}$ & $\begin{array}{c}140 \\
28 \\
\end{array}$ & $\begin{array}{l}- \\
-\end{array}$ \\
\hline$L I C$ & PIT & CIT & TGS & SSC \\
\hline Long run buoyancy & $\begin{array}{c}1.632 \\
(1.601)\end{array}$ & $\begin{array}{l}-6.163 \\
(7.499)\end{array}$ & $\begin{array}{c}\mathbf{0 . 9 0 2 * * *} \\
(0.141)\end{array}$ & $\begin{array}{c}1.060 * * * \\
(0.209)\end{array}$ \\
\hline Short run buoyancy & $\begin{array}{c}0.460 \\
(1.428)\end{array}$ & $\begin{array}{c}2.339 * * * \\
(0.694)\end{array}$ & $\begin{array}{c}1.506 * * * \\
(0.421)\end{array}$ & $\begin{array}{c}1.369 \\
(0.963)\end{array}$ \\
\hline Speed of adjustment & $\begin{array}{c}-0.869 * * * \\
(0.294)\end{array}$ & $\begin{array}{c}-1.203^{* * *} \\
(0.242)\end{array}$ & $\begin{array}{c}-0.948 * * * \\
(0.226)\end{array}$ & $\begin{array}{c}-0.840 * * * \\
(0.224)\end{array}$ \\
\hline $\begin{array}{c}\text { Observations } \\
\text { \# Countries }\end{array}$ & $\begin{array}{l}88 \\
17\end{array}$ & $\begin{array}{l}87 \\
17\end{array}$ & $\begin{array}{c}160 \\
32\end{array}$ & $\begin{array}{c}40 \\
7\end{array}$ \\
\hline
\end{tabular}

Note: Estimation of Equation (3) by PMG estimator (see main text for details). Bold italic means statistically greater than one at 5 percent level; bold means statistically not different from one at 5 percent level. Standard errors in parenthesis. $* * *, * * *$ denote statistical significance at the 10,5 and 1 percent levels, respectively. 


\section{References}

Agbeyegbe, T. D., J. G. Stotsky, and A. Wolde-Mariam (2004). Trade liberalization, Exchange Rate Changes, and Tax Revenue in Sub-Saharan Africa. IMF Working Paper 04/178, International Monetary Fund.

Ahmad, E and N. Stern (1991), The Theory and Practice of Tax Reforms in Developing Countries, Cambridge University Press.

Ahsan, S.M. and Wu, S. (2005). Tax Structure and Reform in China, 1979-2002. Mimeo Department of Economics, Concordia University, Canada.

Ariyo, A. (1997), "Productivity of the Nigerian Tax System: 1970 - 1990”, Research paper No. 67. Nairobi: African Economic Research Consortium.

Bahl, R.W. (2003), "Reaching the Hardest to Tax: Consequences and Possibilities", paper presented at the "Hard to Tax: An International Perspective" conference, Andrew Young School of Policy Studies, Georgia State University, May 15-16

Belinga V., D. Benedek, R. A. de Mooij and J. Norregaard (2014), “Tax Buoyancy in OECD Countries", IMF Working Paper 110

Bilquees, F. (2004), "Elasticity and Buoyancy of the Tax System in Pakistan", Pakistan Development Review, 43(1), 73-93

Blanchard, O., Dell'Aricia, G., and Mauro P. (2010), "Rethinking Macroeconomic Policy”. IMF Staff Position Note, SPN/10/03.

Bouthevillan, C., P. Cour-Thimann, G. Van den Dool, P. Hernandez de Cos, G. Langenus, M. Mohr, S. Momigliano and M. Tujula (2001) "Cyclically Adjusted Budget Balances: An Alternative Approach”, ECB Working Paper No. 77.

Bruce, Donald, William F. Fox, and M.H. Tuttle (2006). "Tax Base Elasticities: A MultiState Analysis of Long-Run and Short-Run Dynamics," Southern Economic Journal, 73(2), 315-341.

Chelliah, R.J., Baas, H.J., and Kelly, M. R. (1975). Tax Ratios and Tax Effort in Developing Countries, 1969-71. IMF Staff Papers, 22(1), 187-205

Chipeta, C. (1998). “Tax Reform and Tax yield in Malawi”, AERC Research Paper No. 81. Nairobi: AERC

Choudhry, N.N. (1979), "Measuring the Elasticity of Tax Revenue: A Divisia Index Approach". IMF Staff Paper, 26. 
Cotton, J.J. (2012), "The Buoyancy and Elasticity of Non-Oil Tax Revenues in Trinidad and Tobago (1990-2009)", Central Bank of Trinidad and Tobago Working Paper.

Ehrhart, H. (2009). Assessing the relationship between Democracy and Domestic taxes in developing countries. CERDI, Etudes et Documents, E.30

Evans, P. (1997), "How fast do economies converge", Review of Economics and Statistics, 46, 1251-1271.

Furceri, D., Jalles, J. T. (2016), "Fiscal Stabilization: Determinants and Effects", IMF Working Paper (forthcoming)

Ghura, D. (1998), 'Tax revenue in Sub-Saharan Africa: Effects of Economic Policies and Corruption', IMF Working Paper, WP/98/135. September. Internet version

Giorno, C., Richardson, P. and P. Van den Noord (1995), "Estimating Potential Output, Output Gaps and Structural Budget Balances”, OECD Economics Department Working Papers 24

Girouard, N. and C. Andre (2005), Measuring Cyclically-Adjusted Budget Balances for the OECD Countries, OECD Economics Department Working Papers 434.

Granger, C.W.J. and T. Terasvirta (1993). "Modelling Nonlinear Economic Relationships". Oxford University Press.

Hindrichs, H.H. (1966) “A General Theory of Tax Structure Change During Economic Development”, Harvard Law School International Tax Programme.

Im, K. S., Pesaran, M. H. and Shin, Y. (2003), "Testing for Unit Roots in Heterogeneous Panels," Journal of Econometrics, 115, 53- 74.

International Monetary Fund (2015), “Current Challenges in Revenue Mobilization: Improving Tax Compliance", IMF Board Paper.

Khattry, Barsha and J. Mohan Rao (2002), "Fiscal Faux Pas?: An Analysis of the Revenue Implications of Trade Liberalization," World Development, Vol. 30, No. 8, pp. 14311444.

Kusi, N. K. (1998), “Tax Reform and Revenue Productivity in Ghana”, AERC Research Paper Number Seventy-four. Nairobi: AERC

Laeven, L. and Valencia, F. (2008), "Systemic Banking Crises: A New Database,” IMF Working Paper No. 08/224.

Lee, K., Pesaran, M. H. and Smith, R. P. (1997), "Growth and Convergence in a MultiCountry Empirical Stochastic Solow model”, Journal of Applied Econometrics, 12 , 357-392. 
Leuthold, J.H. (1991). Tax Shares in Developing Economies: A Panel Study, Journal of Development Economics, 35,173-185

Lotz, J.R. and Morss, E.R. (1967). Measuring 'Tax Effort' in Developing Countries. IMF Staff Papers, 14, 479-497

Maddala, G. S. and Wu, S. (1999), "A Comparative Study of Unit Root Tests with Panel Data and a New Simple Test", Oxford Bulletin of Economics and Statistics, 61, 631652.

Mahdavi, S. (2008). The Level and Composition of Tax Revenue in Developing Countries: Evidence from Unbalanced Panel Data. International Review of Economics and Finance, 17,607-617

Osoro, N.E. (1993), "Revenue Productivity Implications of Tax Reform in Tanzania". Research Paper No. 20, Nairobi; African Economic Research Consortium.

Osoro, N.E. (1995), "Tax Reforms in Tanzania: Motivations, Directions and Implications”. Research paper No. 38. Nairobi: African Economic Research Consortium.

Pesaran, M. H. (2007), “A simple Panel Unit Root Test in the Presence of Cross Section Dependence", Journal of Applied Econometrics, 22(2), 265-312.

Pesaran, M. H. and Smith, R. P. (1995), "Estimating Long-Run Relationship from Dynamic Heterogeneous Panels", Journal of Econometrics, 68, 79-113.

Pesaran, M. H., Shin, Y. and Smith, R. P. (1999), "Pooled Mean Group Estimation of Dynamic Heterogeneous Panels", Journal of American Statistical Association, 94, 3154.

Reinhart, C and K. Rogoff (2011), "From Financial Crash to Debt Crisis," American Economic Review, 101, 1676-1706.

Sancak, Cemile, Ricardo Velloso, and Jing Xing (2010), "Tax Revenue Response to the Business Cycle," IMF Working Paper 10/71.

Skeete, R., Coppin, K. and Boamah, D. (2003), "Elasticities and Buoyancies of the Barbados Tax System, 1977 - 1999”. Central Bank of Barbados.

Stotsky, J.G. and A. Wolde-Mariam (1997), 'Tax effort in Sub-Saharan Africa', IMF Working Paper, WP/97/107, September.

Tanzi, V. (1987). Quantitative Characteristics of the Tax System of Developing Countries. The Theory of Taxation for Developing Countries, New York: Oxford University Press

Tanzi, V. and Zee, H., 2000, "Tax Policy for Emerging Markets: Developing Countries," Working Paper WP/00/35, Washington, D.C.: International Monetary Fund 
Teera, J. (2002): "Tax Performance: A Comparative Study", Department of Economics, University of Bath, Working Paper No. 01/2002.

Upender, M. (2008), "Degree of Tax Buoyancy in India: An Empirical Study”, International Journal of Applied Econometrics and Quantitative Studies, 5(2) 